\title{
Şiran (Gümüşhane) İlçe Merkezi Su Kaynaklarının Kalitesi ve Hidrojeokimyasal Özelliklerinin Değerlendirilmesi
}

\author{
Ümmühan Semiz ${ }^{1} \oplus$, Mehmet Ali Gücer ${ }^{1, \oplus}$, Selçuk Alemdağ ${ }^{1 \oplus}$ \\ ${ }^{1}$ Gümüşhane Üniversitesi, Mühendislik ve Doğa Bilimleri Fakültesi, Jeoloji Mühendisliği Bölümü, 29100, Gümüşhane.
}

\section{Özet}

İnceleme alanı, Gümüşhane (KD Türkiye) ilinin güneybatısında yer alan Şiran ilçe merkezini kapsamaktadır. Bu çalı̧̧mada, ilçe merkezindeki suların hidrojeokimyasal karakteristikleri incelenmiş ve metal element içerikleri belirlenmiştir. İnceleme alanında, temel birimleri kumtaşı, kiltaşı, marn, şeyl ve tüf ardışımından meydana gelen Eosen yaşlı Kelkit Formasyonu oluşturmakta olup Kuvaterner yaşlı alüvyon ile uyumsuz bir şekilde örtülmüştür. Bu birimler hidrojeolojik özelliklerine göre taneli gözenekli serbest akiferleri oluşturmaktadır. Örneklerin pH, özgül elektriksel iletkenlik (ÖEI) ve toplam sertlik (Fr ${ }^{\circ}$ ) değerleri sirasiyla 5.41-7.48, 106.9-141.3 $\mu \mathrm{S} / \mathrm{cm}$ ve 4.72-6.78 (n=18) arasında değişmektedir. Bu veriler, Kita İçi Yerüstü Su Kaynakları sinıflamasına göre, suların çoğunlukla I. ve II. sinıf, az oranda ise III. sinıf kalitede olduğunu göstermektedir. İnceleme alanındaki sular genelde Ca-Mg-HCO 3 tipli karbonatlı $(\mathrm{Ca}+\mathrm{Mg}>\mathrm{Na}+\mathrm{K})$ olup, zaylf asit kökleri güçlü asit köklerinden $\left(\mathrm{HCO}_{3}>\mathrm{SO}_{4}+\mathrm{Cl}\right)$ daha fazladır. Inceleme alanindaki suların $(\mathrm{Ca}+\mathrm{Mg}) /\left(\mathrm{SO}_{4}+\mathrm{HCO}_{3}\right)$ oranlarl sularda silikat ayrışmasının etkisini işaret etmekte, $\mathrm{Cl} /\left(\mathrm{Cl}+\mathrm{HCO}_{3}\right)$ ve $(\mathrm{Na}+\mathrm{K}) /(\mathrm{Na}+\mathrm{K}+\mathrm{Ca})$ oranları ise, bu suların kimyasının kayaç yapıcı minerallerin kimyasal ayrışması tarafindan kontrol edildiğini, dolayısıyla su-kayaç etkileşimini göstermektedir. Su örneklerindeki çözünmüş potansiyel toksik element içerikleri, birkaç örnek dişında, kabul edilebilir sınırlar arasında dağılım sergilemektedir. Sonuç olarak, elde edilen hidrojeokimyasal veriler, inceleme alanındaki suların genel olarak içme suyu açısından iyi sınıf sular kategorisinde yer aldığı̆n göstermiştir.

\section{$\underline{\text { Anahtar Sözcükler }}$}

Hidrojeokimya, pH, Su Kalitesi, Şiran (Gümüşhane)

\section{Investigation of Hydrogeochemical Characteristics and Quality of the Water Resources in Şiran (Gümüşhane) District Center, Turkey}

\begin{abstract}
The study area is located of Şiran District Center in the southwest of Gümüşhane (NE Turkey). In this study, hydrogeochemical characteristics of water resources in district center were examined and metal element contents were determined. In the study area, the basement rocks are represented by Eocene Kelkit formation, which is composed of sandstone, claystone, marl, shale and tuff, and this unit is covered unconformably by the Quaternary aged alluvium. These units form granular porous unconfined aquifers according to the hydrogeological features. The $\mathrm{pH}$, specific conductance $(\mathrm{SC})$ and hardness $\left(\mathrm{Fr}^{\circ}\right)$ values of the water resources in the study area varied between 5.41-7.48, 106.9-141.3 $\mu \mathrm{S} / \mathrm{cm}$ and 4.72-6.78 $(n=18)$, respectively. According to the classification of Intra-Continental Water Resources, these data show that the samples are mostly class-I and II, rarely class-III water quality characteristics. The water resources in the study area are generally classified as $\mathrm{Ca}-\mathrm{Mg}-\mathrm{HCO}$ type carbonated $(\mathrm{Ca}+\mathrm{Mg}>\mathrm{Na}+\mathrm{K})$, and generally their weak acids are more than strong acids $\left(\mathrm{HCO}_{3}>\mathrm{SO}_{4}+\mathrm{Cl}\right)$. In the study area, $(\mathrm{Ca}+\mathrm{Mg}) /\left(\mathrm{SO}_{4}+\mathrm{HCO}_{3}\right)$ ratios indicated the effect of silicate weathering in the waters, and the $\mathrm{Cl} /\left(\mathrm{Cl}+\mathrm{HCO}_{3}\right)$ and $(\mathrm{Na}+\mathrm{K}) /(\mathrm{Na}+\mathrm{K}+\mathrm{Ca})$ ratios show that the chemistry of waters is controlled by the chemical weathering of rock-forming minerals, hence, reflect the water-rock interaction. Except for a few, the concentration of dissolved potentially toxic elements in the water samples were distributed within acceptable limits. Consequently, the hydrogeochemical results showed that the water resources in the study area were in the category of good class waters in terms of drinking water.
\end{abstract}

$\underline{\text { Keywords }}$

Hydrogeochemistry, pH, Water Quality, Şiran (Gümüşhane)

\section{Giriş}

$\mathrm{Su}$, canlıların yaşamlarını sürdürmesi için gereken en önemli temel unsurlardandır. Yaşamsal faaliyetlerin devam ettirilebilmesi, suların etkin bir şekilde kullanılmasına ve su kalitesinin izlenerek kontrol altında tutulmasına bağlıdır. Yüzey ve yeraltı sularının kalitesi (fiziksel, kimyasal, mikrobiyolojik vb.) suların içme, kullanma ve sulamaya uygunluğunun belirlenmesinde ve kalitesinin korunmasında en önemli kriterleri oluşturmaktadır. 
Bunun yanı sıra biyolojik sistemlerde değişik görevleri olan $\mathrm{H}, \mathrm{Na}$, K gibi elementler suda çözünmüş olarak bulunmakta ve canlıların başlıca besin maddelerini oluşturmaktadır. Bu özellik, suda çözünmüş olarak bulunan element düzeylerinin önemini ortaya koymaktadır. Vücuttaki bütün fizyolojik olayların yürütülmesinde su ya doğrudan ya da dolaylı olarak metabolik işlemlere katılır. Suyun insanlara hijyenik olarak, içerisinde $\mathrm{As}, \mathrm{Cu}, \mathrm{Pb}$, gibi zararlı kimyasal maddeleri ve patojen mikroorganizmaları içermeyecek özellikte, sağlanması gerekmektedir.

Gümüşhane (KD Türkiye) genelinde, il merkezi içme suyu kalitesine yönelik şimdiye kadar yapılmış birkaç çalışma (Gültekin 1998; Gültekin ve Dilek 2005; Uslu 2014; Sipahi ve Uslu 2016) olmasına rağmen, Şiran içme sularının hidrojeokimyasal karakteristiklerine yönelik oldukça sınırlı sayıda çalışma bulunmaktadır. Dolayısıyla, bu çalışma kapsamında Şiran'da, başta içme suyu olarak kullanılan kaynakların hidrojeokimyasal özellikleri ve su kalitesine yönelik araştırmalar gerçekleştirilmiştir. Yerleşim yerindeki suların özelliklerinin ortaya konulması, bölgede bulunan mevcut kaynakların kullanılabilirliğinin belirlenmesi açısından önemlidir.

\section{2. İnceleme Alanının Jeolojisi ve Hidrojeolojik Özellikleri}

Ülkemiz, jeolojik olarak Alp-Himalaya dağ oluşum kuşağında yer almakta ve daha yaşlı orojenik dönemleri de temsil etmektedir. Dolayısıyla, Türkiye farklı jeolojik kökenlere sahip birçok tektonik birliğin Geç Tersiyer dönemde bir araya gelmesi sonucu oluşmuş ve birçok tektono-stratigrafik birlikten meydana gelmiştir (Okay 2008; Göncüoğlu 2010). Karadeniz'in güneydoğu kesimi boyunca uzanan ve inceleme alanının da içerisinde yer aldığı Doğu Pontidler ise, yaklaşık $500 \mathrm{~km}$ uzunluğa ve $100 \mathrm{~km}$ geniş̧liğe sahip bir orojenik kuşağı temsil etmektedir. Bu kuşak, Geç Kretase (Senoniyen) döneminde kuzeyde Avrasya levhası altına yiten Neotetis okyanusunun kuzey kolu üzerinde gelişmiş ve iyi korunmuş eski bir adayayı olarak bilinmektedir (Akın 1979; Şengör ve Yılmaz 1981; Akıncı 1984; Okay ve Şahintürk 1997; Yılmaz vd. 1997). Doğu Pontid orojenik kuşağı, tektonik olarak Sakarya Zonu'nun doğu kesimini teşkil etmektedir (Okay 1989; Okay ve Tüysüz 1999) (Şekil 1a).

İnceleme alanının temel birimlerini Karbonifer yaşlı metamorfitler (Topuz ve Altherr 2004; Topuz vd. 2007) ve onları keserek yerleşen Karbonifer yaşlı plütonlar (Y1lmaz 1972; Çoğulu 1975; Topuz vd. 2010; Dokuz 2011; Kaygusuz vd. 2016; Karslı vd. 2016) oluşturmuştur. Bölgede Paleozoyik temel, Alt-Orta Jura yaşlı volkanik ve volkanoklastik kayaçlardan oluşan ve Liyasik transgresyon (200-190 My) sonucu meydana gelen Şenköy Formasyonu tarafindan uyumsuz olarak örtülmüştür (Topuz vd. 2007; Kandemir ve Y1lmaz 2009). Volkanoklastik istif üzerine Dogger- MalmAlt Kretase yaşlı sığ platform karbonatları uyumlu olarak gelmiş olup, bu birim genel olarak gri-bej renkli, kalın ve masif katmanlı, zengin bentik foraminifer fosilleri içeren ve sı̆̆ denizel bir istif özelliği sunmaktadır (Pelin 1977). Üst Kretase, taban kesimlerinde türbiditik istif, üst kesimlerinde volkanik ağırlıklı kayaçlarla (Sipahi 2005; Sipahi ve Sadıklar 2014; Sipahi vd. 2019; 2020) temsil edilirken, tüm bu birimler üzerine taban çakılltaşı ile uyumsuz olarak gelen Eosen ise üst kesimlere doğru volkanik tüf, nummulitli kireçtaşı ve volkanitler ile temsil edilmektedir (Tokel 1972; Bergougnan 1976). Kuvaterner yaşlı alüvyon ve yamaç molozları inceleme alanının en genç birimini oluşturur (Şekil 1b).

İnceleme alanında baskın litolojiyi Kelkit Formasyonuna ait çakıltaşı, kumtaşı, marn, kumlu kireçtaşı ve şeyl ardışımından oluşan Eosen yaşlı birimler ve alüvyon/yamaç molozu birikimleri meydana getirmektedir.

İnceleme alanı deniz seviyesinden 1400 metre yükseklikte yer almakta ve arazi bakımından daha çok bir platoyu andırmaktadır. Bununla birlikte, en önemli akarsuyunu Şiran çayı ve küçük kolları oluşturmaktadır. Özellikle ŞiranTersun çayları ve dereler boyunca yayılım gösteren alüvyon ve yamaç molozu, akarsular tarafindan taşınan kil, kum, çakıl, yamaç döküntüleri gibi tutturulmamış tortul malzemeden meydana gelmekte olup, çalışma alanında taneli gözenekli serbest akifer ortamı temsil etmektedir. Alüvyon tarafindan örtülen Kelkit Formasyonu çok ince ve ince-orta tabakalı, açık yeşilimsi rengi ve yumuşak topografik görünümü ile dikkat çekmekte, genel olarak çakıltaşı, kumtaşı, kumlu kireçtaşı, şeyl, tüf ardalanmalı fliş özelliğinde olup (Tokel 1972; Bergougnan 1976) oldukça iyi tabakalı ve yer yer küçük ölçekli antiklinal ve senklinal kıvrımlı olarak görülmektedir. İstif içerisinde devamlılık arz etmeyen ve kalınlıkları birkaç cm'den birkaç metreye kadar değişen çakıltaşlı seviyeler gözlenmektedir. Birim içerisinde bol gözenekli ve çatlaklı tüf ve kumtaşları ile erime boşluklu kireçtaşları geçirimlilik, depolama ve iletimlilik açısından akifer özelliği göstermesi ve taban kaya olarak marn, kiltaşı ve şeyl ara katkılı seviyelerden oluşması birimin serbest akifer olma özelliğinde olduğunu göstermektedir. Dolayısıyla, inceleme alanında yayılım gösteren alüvyon örtü ve Kelkit Formasyonu litolojik açıdan serbest akifer özelliğindedir. Bu litolojik birimlerin akifer yapısını daha iyi ifade edebilmek için, Şekil 1c'de yeraltı suyu akım modelini gösteren basit bir hidrojeolojik model oluşturulmuştur. Bu modele göre akifer sistem Şiran Çayı'nı beslerken, birim geçirimli olduğu için aynı zamanda Şiran Çayı'ndan beslenmektedir. 


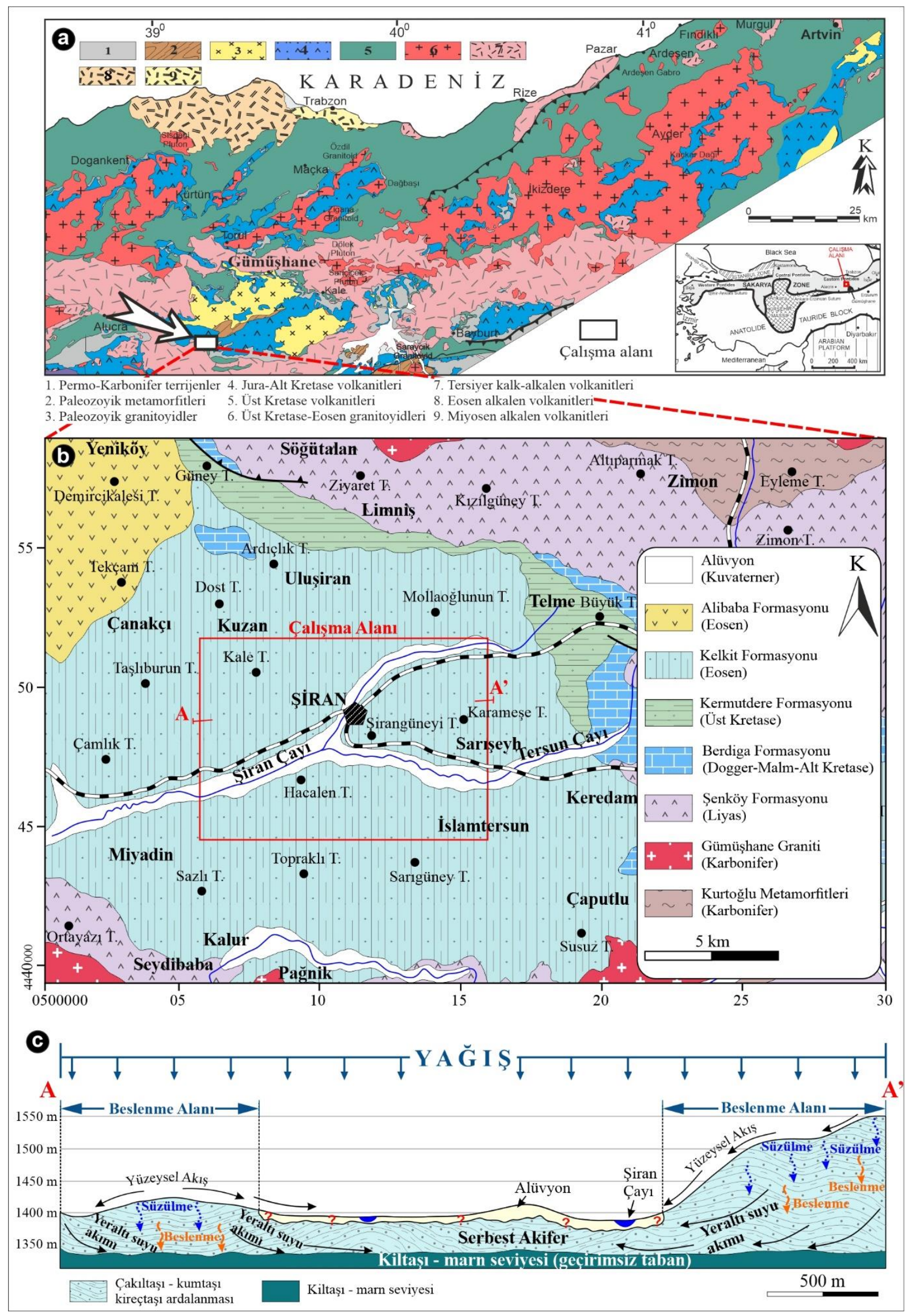

Şekil 1: a) Doğu Pontidlerin genelleştirilmiş jeoloji haritası, b) inceleme alanı ve yakın çevresinin jeolojisi (Güven 1993), c) hidrojeolojik model 


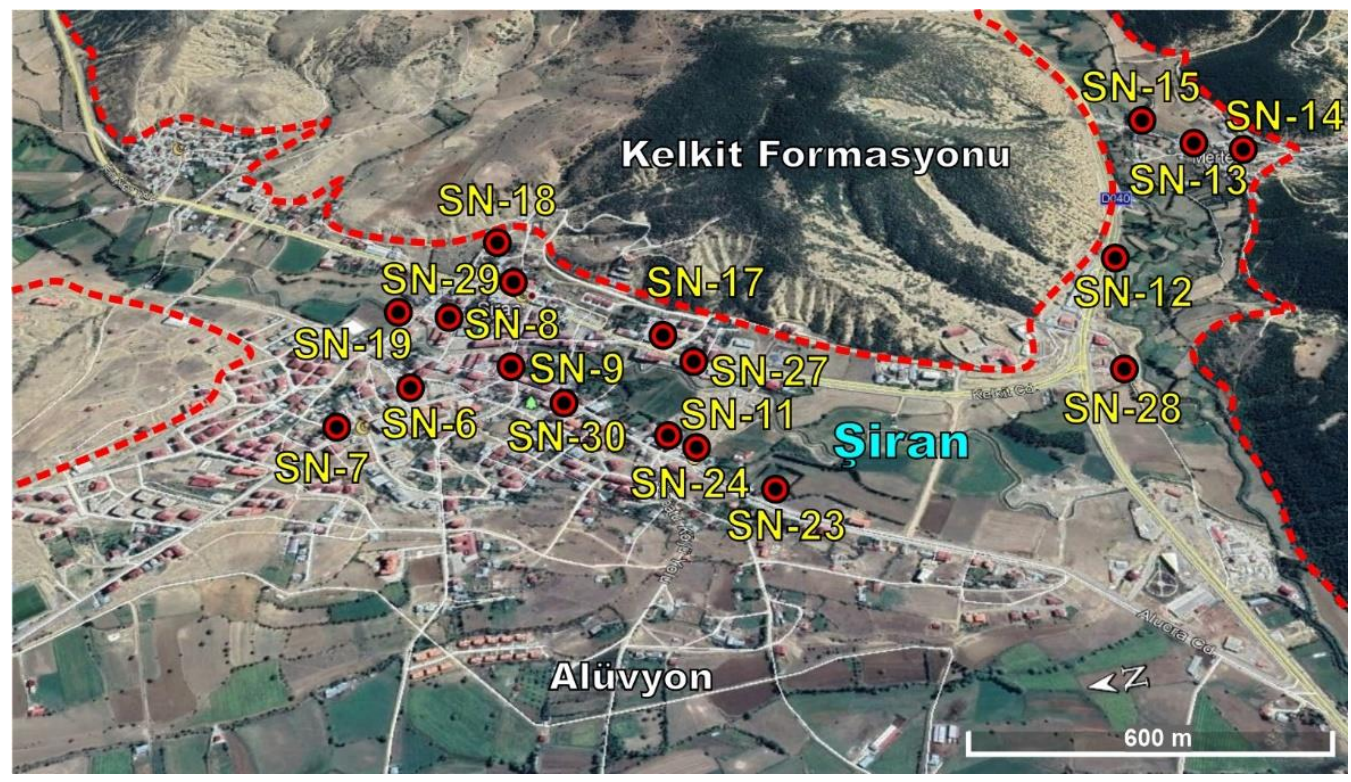

Şekil 2: Şiran ilçe merkezinden alınan su örneklerinin konumu

\section{Malzeme ve Yöntem}

İnceleme alanında, Şubat 2019 döneminde toplam 18 farklı su kaynağından (Şekil 2, Tablo 1) örnekleme yapılmış ve hidrojeokimyasal özellikleri belirlenmiştir. Her bir örnek polietilen örnek şişesi ile TS 266'ya uygun olarak alınmış ve etiketlenerek analiz sürecine kadar $+4^{\circ} \mathrm{C}$ 'de muhafaza edilmiştir.

Tablo 1: Inceleme alanından alınan su örneklerinin yerleri ve konumu

\begin{tabular}{cllcc}
\hline S.No & Örnek No & Alındığı Yer & \multicolumn{2}{c}{ Konum (Boylam-Enlem) } \\
\hline 1 & SN-6 & Mertekli Mahallesi Merkez Çeşmesi & 39.124367 & 40.191616 \\
2 & SN-7 & Mertekli Mahallesi Meydan Çeşmesi & 39.122474 & 40.203658 \\
3 & SN-8 & Meydan Çeşmesi & 39.127087 & 40.190960 \\
4 & SN-9 & Çeşme (isimsiz) & 39.124864 & 40.189755 \\
5 & SN-11 & Çeşme (isimsiz) & 39.121734 & 40.187059 \\
6 & SN-12 & Göze (isimsiz) & 39.126900 & 40.177936 \\
7 & SN-13 & Merkez Çarş1 Camii Şadırvanı & 39.132074 & 40.173739 \\
8 & SN-14 & Tekke Camii Şadırvanı & 39.130866 & 40.172316 \\
9 & SN-15 & Esentepe Camii Şadırvanı & 39.131724 & 40.174284 \\
10 & SN-17 & Şeyhi Şirani Çeşmesi & 39.125417 & 40.186895 \\
11 & SN-18 & Tekke Gözesi & 39.155824 & 40.219212 \\
12 & SN-19 & Osman Keleş Hayratı & 39.127563 & 40.191941 \\
13 & SN-23 & Çeşme (isimsiz) & 39.119554 & 40.185389 \\
14 & SN-24 & Çeşme (isimsiz) & 39.121243 & 40.186599 \\
15 & SN-27 & Göze (isimsiz) & 39.124392 & 40.186402 \\
16 & SN-28 & Çeşme (isimsiz) & 39.124317 & 40.179633 \\
17 & SN-29 & Çeşme (isimsiz) & 39.217279 & 40.168581 \\
18 & SN-30 & Göze (isimsiz) & 39.252654 & 40.170074 \\
\hline
\end{tabular}

Suların hidrojen iyonu aktivitesi $(\mathrm{pH})$, toplam sertlik $\left(\mathrm{F}^{\circ}\right)$, özgül elektriksel iletkenlik (ÖEİ- $\left.\mu \mathrm{S} / \mathrm{cm}\right)$ ve kimyasal (çeşitli anyon ve katyon) analizleri Gümüşhane Üniversitesi, Mühendislik ve Doğa Bilimleri Fakültesi, Gıda Mühendisliği

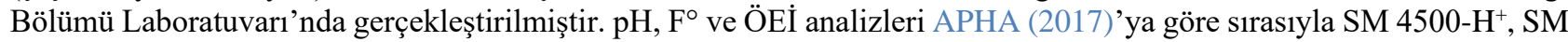
2340 C. EDTA (titrasyon) ve SM 2510 metoduna göre analiz edilmiștir. Sülfat $\left(\mathrm{SO}_{4}^{-2}\right)$, bikarbonat $\left(\mathrm{HCO}_{3}{ }^{-}\right)$ve klorür $\left(\mathrm{Cl}^{-}\right)$gibi anyon analizlerinde de farklı teknikler kullanılmış olup APHA (2017)'ya göre sırasıyla türbidimetrik (SM 4500$\mathrm{SO}_{4}^{-2}$.E), titrasyon (SM 2320 B. alkalinite) ve titrimetrik (SM 4500-Cl- klorür) yöntemler kullanılmıştır. Katyon ve ağır metal (Ca, Mg, Na, K, Fe, Zn, Cu, Al, Mn, Cd, Co, Ni, Pb, Cr) analizleri ise emisyon spektrometresi yöntemine göre (Balaram vd. 2013; Vysetti vd. 2014), Agilent 7700 marka ICP-MS (indüktif eşleşmiş plazma-kütle spektrometresi) cihazı kullanılarak gerçekleştirilmiştir. Metallerin ölçümünde kullanılan cihaza ait çalışma koşulları ve performansı ile ilgili bilgiler Tablo 2'de özetlenmiştir (URL-1 2011; Jankowski vd. 2005). 
Tablo 2: ICP-MS cihazının çalışma şartları ve sistemin analitiksel karakteristiği

\begin{tabular}{|c|c|c|c|c|c|c|c|}
\hline $\begin{array}{l}\text { Element } \\
\text { adı }\end{array}$ & $\begin{array}{l}\text { Dalga boyu } \\
(\mathbf{n m})\end{array}$ & $\begin{array}{c}\text { Sisleştirici } \\
\text { Basıncı (kPa) }\end{array}$ & $\begin{array}{l}\text { Kararlılık ve numune } \\
\text { alma süresi (s) }\end{array}$ & $\begin{array}{c}\text { Peristaltik pompa } \\
\text { hızı (rpm) }\end{array}$ & $\begin{array}{l}\mathrm{LOD}^{1} \\
(\mu \mathrm{g} / \mathrm{L})\end{array}$ & $\begin{array}{l}\mathrm{LOQ}^{2} \\
(\mu \mathrm{g} / \mathrm{L})\end{array}$ & $\begin{array}{r}\text { BSS }^{3} \\
(\%)\end{array}$ \\
\hline $\mathrm{Al}$ & 396.152 & 240 & 10 & 15 & 1.4 & 4.7 & 4.9 \\
\hline $\mathrm{Cd}$ & 228.802 & 140 & 10 & 15 & 0.3 & 1 & 0.4 \\
\hline Co & 340.512 & 240 & 10 & 15 & 0.1 & 0.3 & 0.7 \\
\hline $\mathrm{Cr}$ & 425.433 & 240 & 10 & 15 & 0.2 & 0.6 & 1.3 \\
\hline $\mathrm{Cu}$ & 324.754 & 240 & 10 & 15 & 0.3 & 1 & 0.6 \\
\hline $\mathrm{Fe}$ & 371.993 & 120 & 10 & 15 & 1.6 & 5.3 & 1.2 \\
\hline $\mathrm{Mn}$ & 403.076 & 240 & 10 & 15 & 0.4 & 1.3 & 0.7 \\
\hline $\mathrm{Ni}$ & 352.454 & 240 & 10 & 15 & 1 & 3 & 0.9 \\
\hline $\mathrm{Pb}$ & 405.781 & 240 & 10 & 15 & 0.4 & 1.3 & 1.5 \\
\hline $\mathrm{Zn}$ & 213.857 & 140 & 10 & 15 & 1.2 & 4 & 1 \\
\hline $\mathrm{Na}$ & 588.995 & 240 & 10 & 15 & 2.3 & 7.8 & 1.2 \\
\hline K & 766.491 & 240 & 10 & 15 & 3.4 & 11.4 & 0.7 \\
\hline $\mathrm{Ca}$ & 393.366 & 120 & 10 & 15 & 3.2 & 10.6 & 4.7 \\
\hline $\mathrm{Mg}$ & 285.213 & 240 & 10 & 15 & 3.2 & 6.4 & 6.4 \\
\hline
\end{tabular}

${ }^{1}$ LOD: Gözlenebilme sinırl, ${ }^{2}$ LOQ: Tayin sinırı, ${ }^{3}$ BSS: Bă̆ll Standart Sapma

Sularda pozitif ve negatif yüklerin toplamı eşit olması gerektiğinden, analizlerin doğruluğu majör iyonlar için elektriksel yük dengesinden tahmin edilebilmektedir (örneğin, Stumm ve Morgan 1970; Appelo ve Postma 2005). Çalışma alanından derlenen sularda, analiz sonuçlarının doğruluğu Stumm ve Morgan (1970) tarafından önerilen denklem (1) ile test edilmiş, analitik hata oranları (\%fark) ise Appelo ve Postma (2005) tarafindan önerilen elektronötralite (\%e) denklemi (2) kullanılarak hesaplanmıştır.

$\mid \sum$ anyon- $\sum$ katyon $\mid \leq\left(0.1065+0.0155 \times \sum\right.$ anyon $)$

Elektriksel denge $(\% \mathrm{e})=\frac{\sum \text { katyon }-\sum \text { anyon }}{\sum \text { katyon }+\sum \text { anyon }} \times 100$

Hemen hemen tüm analiz sonuçlarında \%2'ye varan hatalar kaçınılmazdır, ancak \%5'in üzerindeki sapmalarda örnekleme ve analitik prosedürler yeniden gözden geçirilmelidir (Appelo ve Postma 2005). Çalışma alanındaki suların analiz sonuçlarında hata oranı $(\% \mathrm{e})-4.48$ ile $3.92(\mathrm{n}=18)$ aralığında değişmekte olup (Tablo 3), yukarıda verilen ölçütler dikkate alındığında, elde edilen sonuçların kabul edilebilir düzeyde olduğu görülmektedir.

\section{Bulgular ve Tartışma}

\subsection{Suların Hidrojeokimyasal Karakteristikleri}

Örneklenen sular ana katyon ve anyonları açısından analiz edilmiş ve sonuçlar Tablo 3'de verilmiştir. Bununla birlikte söz konusu sularda $\mathrm{pH}$, ÖEİ ve $\mathrm{F}^{\circ}$ fizikokimyasal parametreler de belirlenmiştir. 
Tablo 3: Inceleme alanında örneklerin $\mathrm{pH}$, ÖEl, $F^{\circ}$ ve majör (anyon-katyon) iyon analiz sonuçları ile hesaplanan yükdenge hatası (ydh) oranları (\%fark)

\begin{tabular}{|c|c|c|c|c|c|c|c|c|c|c|c|c|}
\hline & $\begin{array}{r}\text { Parametre } \\
\text { Birimi }\end{array}$ & $\begin{array}{r}\text { ÖEI } \\
\mu S / \mathbf{c m}\end{array}$ & $\begin{array}{r}\text { Sertlik } \\
\text { Fr }^{\circ}\end{array}$ & $\begin{array}{l}\mathrm{SO}_{4}^{-2} \\
\mathrm{mg} / \mathrm{L}\end{array}$ & $\begin{array}{r}\mathrm{Cl}^{-} \\
\mathrm{mg} / \mathrm{L}\end{array}$ & $\begin{array}{r}\mathrm{HCO}_{3}^{-} \\
\mathrm{mg} / \mathrm{L}\end{array}$ & $\begin{array}{r}\mathrm{Ca} \\
\mathrm{mg} / \mathrm{L}\end{array}$ & $\begin{array}{r}\mathrm{Mg} \\
\mathrm{mg} / \mathrm{L}\end{array}$ & $\begin{array}{r}\mathrm{Na} \\
\mathrm{mg} / \mathrm{L}\end{array}$ & $\begin{array}{r}\mathrm{K} \\
\mathrm{mg} / \mathrm{L}\end{array}$ & $\begin{array}{r}\text { ydh } \\
\text { \% fark }\end{array}$ & $\begin{array}{c}\text { Grafik } \\
\text { Sembolü }\end{array}$ \\
\hline Örnek & pH & & & & & & & & & & & \\
\hline SN-6 & 7.48 & 141.3 & 6.22 & 7.4 & 17.9 & 80.0 & 13.0 & 7.2 & 12.8 & 0.81 & -3.87 & $\Delta$ \\
\hline $\mathrm{SN}-7$ & 7.13 & 117.0 & 5.41 & 18.7 & 11.2 & 56.0 & 13.1 & 5.2 & 11.4 & 0.44 & -1.07 & प्र \\
\hline $\mathrm{SN}-8$ & 7.01 & 110.9 & 4.83 & 14.5 & 10.8 & 47.7 & 11.1 & 5.0 & 11.1 & 0.36 & 2.45 & $\theta$ \\
\hline SN-9 & 6.76 & 140.8 & 6.24 & 10.9 & 19.3 & 74.4 & 13.4 & 7.0 & 12.6 & 0.82 & -4.48 & كُ \\
\hline SN-11 & 6.99 & 111.1 & 4.72 & 19.9 & 11.2 & 47.7 & 10.9 & 4.9 & 11.2 & 0.36 & -2.46 & $\bigoplus$ \\
\hline SN-12 & 6.88 & 110.3 & 5.09 & 21.4 & 10.4 & 49.1 & 13.0 & 4.5 & 11.1 & 0.35 & -1.10 & 凶 \\
\hline SN-13 & 6.96 & 110.7 & 5.14 & 21.6 & 11.1 & 53.3 & 13.1 & 4.5 & 11.2 & 0.36 & -3.63 & 田 \\
\hline SN-14 & 6.95 & 110.3 & 5.23 & 22.4 & 13.5 & 50.5 & 13.3 & 4.7 & 11.1 & 0.36 & -4.23 & خ \\
\hline SN-15 & 6.96 & 140.5 & 6.78 & 12.4 & 13.2 & 74.4 & 14.8 & 7.5 & 12.9 & 0.79 & 2.30 & 本 \\
\hline SN-17 & 6.88 & 110.6 & 5.20 & 21.5 & 11.1 & 44.9 & 12.8 & 4.9 & 10.8 & 0.32 & 0.62 & $x$ \\
\hline SN-18 & 6.89 & 106.9 & 5.09 & 20.5 & 9.8 & 53.3 & 12.8 & 4.6 & 10.8 & 0.31 & -2.55 & 4 \\
\hline SN-19 & 6.93 & 110.1 & 5.08 & 22.3 & 11.6 & 44.9 & 12.7 & 4.7 & 11.0 & 0.34 & -0.83 & 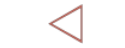 \\
\hline SN-23 & 6.67 & 128.1 & 5.82 & 20.4 & 12.0 & 65.9 & 13.4 & 6.0 & 11.9 & 0.55 & -4.14 & $\nabla$ \\
\hline SN-24 & 6.52 & 111.1 & 4.83 & 20.8 & 10.2 & 49.1 & 12.0 & 4.5 & 10.7 & 0.36 & -2.80 & $\Delta$ \\
\hline SN-27 & 6.35 & 111.4 & 5.36 & 18.2 & 7.8 & 51.9 & 14.0 & 4.5 & 11.2 & 0.35 & 3.92 & 口 \\
\hline $\mathrm{SN}-28$ & 6.20 & 112.0 & 5.24 & 19.8 & 7.3 & 54.7 & 13.4 & 4.6 & 11.1 & 0.36 & 0.83 & $\gamma$ \\
\hline SN-29 & 5.93 & 111.4 & 5.32 & 21.6 & 6.7 & 53.3 & 13.7 & 4.6 & 11.1 & 0.38 & 1.32 & $\diamond$ \\
\hline SN-30 & 5.41 & 111.2 & 5.54 & 22.8 & 5.7 & 56.1 & 14.5 & 4.7 & 11.0 & 0.34 & 1.18 & 4 \\
\hline TİSS $^{1}$ & $6-9$ & $<2500$ & $<50$ & $<250$ & $<250$ & & $<75$ & $<50$ & $<200$ & $<12$ & - & \\
\hline DSTİSS $^{2}$ & $6.5-9.2$ & $<2500$ & $<50$ & $<250$ & $<250$ & & $<200$ & - & $<200$ & - & - & \\
\hline
\end{tabular}

Suların pH değerleri 5.41 ile $7.48(\mathrm{n}=18)$ arasında değişmektedir (Tablo 3). SN-6, SN-7 ve SN-8 örneklerinin pH değerleri $>7$ olduğundan 'alkali sular', diğer örnekler ise $(\mathrm{pH}<7)$ 'asidik sular' sınıfında yer almaktadır. Örnekler, TS 266 (pH; 6-9) ve WHO (6.5-9.2) içme suyu standartları ile karşılaştırıldığında SN-29 (pH: 5.93) ve SN-30 (pH: 5.41) hariç diğer örneklerin verilen limitler içerisinde yer aldığı görülmektedir. Bununla birlikte, 2012 yılında yayımlanan (URL-2 2012) ve 2016 y1lında revize edilen Yerüstü Su Kalitesi Yönetmeliği (Değişik: RG-10/8/2016-29797) Su Kalite Sınıflarına göre inceleme alanındaki sular yüksek kaliteli 'I. sınıf (çok iyi)' su olarak sınıflandırılabilir. Suların ÖEİ değerleri 106.9-141.3 $\mu \mathrm{S} / \mathrm{cm}(\mathrm{n}=18)$ aralığında değişim sergilemekte (Tablo 3) ve TS 266 ile WHO içme-kullanma suları standartlarını $(<2500 \mu \mathrm{S} / \mathrm{cm})$ karşılamaktadır. TS 266 'da önerilen ÖEİ kriterlerine göre incelenen sular I. sınıf su kalitesini yansıtmaktadır. İnceleme alanındaki suların sertliği 4.72 ile $6.78 \mathrm{~F}^{\circ}(\mathrm{n}=18)$ arasında değişim sergilemektedir. Elde edilen bu değerler, SN-6, SN-9 ve SN-15 (6.22-6.78 Fº örneklerinin 'orta sert su', diğer örneklerin ise 'yumuşak su' sınıfinda yer aldığına işaret etmektedir.

Fizikokimyasal özelliklerin yanı sıra, inceleme alanındaki suların kimyasal yapısı ve su tipleri Piper (1944) ve yarı logaritmik Schoeller (1955) sınıflama diyagramları ile belirlenmiştir. Piper sinıflamasına göre, su örneklerinin düşük $\mathrm{SO}_{4}$ ve $\mathrm{Cl}$ içeren $\mathrm{Ca}-\mathrm{Mg}-\mathrm{HCO}_{3}$ tipi sular sınıfında olduğu belirlenmiştir (Şekil 3). Genel olarak karbonatlı $(\mathrm{Ca}+\mathrm{Mg}>\mathrm{Na}+\mathrm{K}$ ) sular sınıfında olan örneklerde, zayıf asit kökleri güçlü asit köklerinden $\left(\mathrm{HCO}_{3}>\mathrm{SO}_{4}+\mathrm{Cl}\right)$ daha fazladır. Schoeller (1955) su sınıflamasına göre, tüm örnekler klorür içerikleri bakımından 'normal klorürlü sular' sınıfına ve sülfat konsantrasyonları açısından 'normal sülfatlı sular' sınıfina girmektedir (Tablo 4). Karbonat miktarı açısından ise 'hipokarbonatlı sular' karakteri sergilemektedir (Tablo 4). Örneklerin katyon-anyon konsantrasyonlarındaki dağılımlarına bakıldığında ise, genel olarak $\mathrm{Ca}>\mathrm{Na}>\mathrm{Mg}>\mathrm{K}$ ve $\mathrm{HCO}_{3}>\mathrm{SO}_{4}>\mathrm{Cl}$ sıralaması sergilediği ve karbonatlı kayaçlardan gelen sular dağılımına benzer yönelim gösterdiği belirlenmiştir (Schoeller 1955), (Şekil 4). 


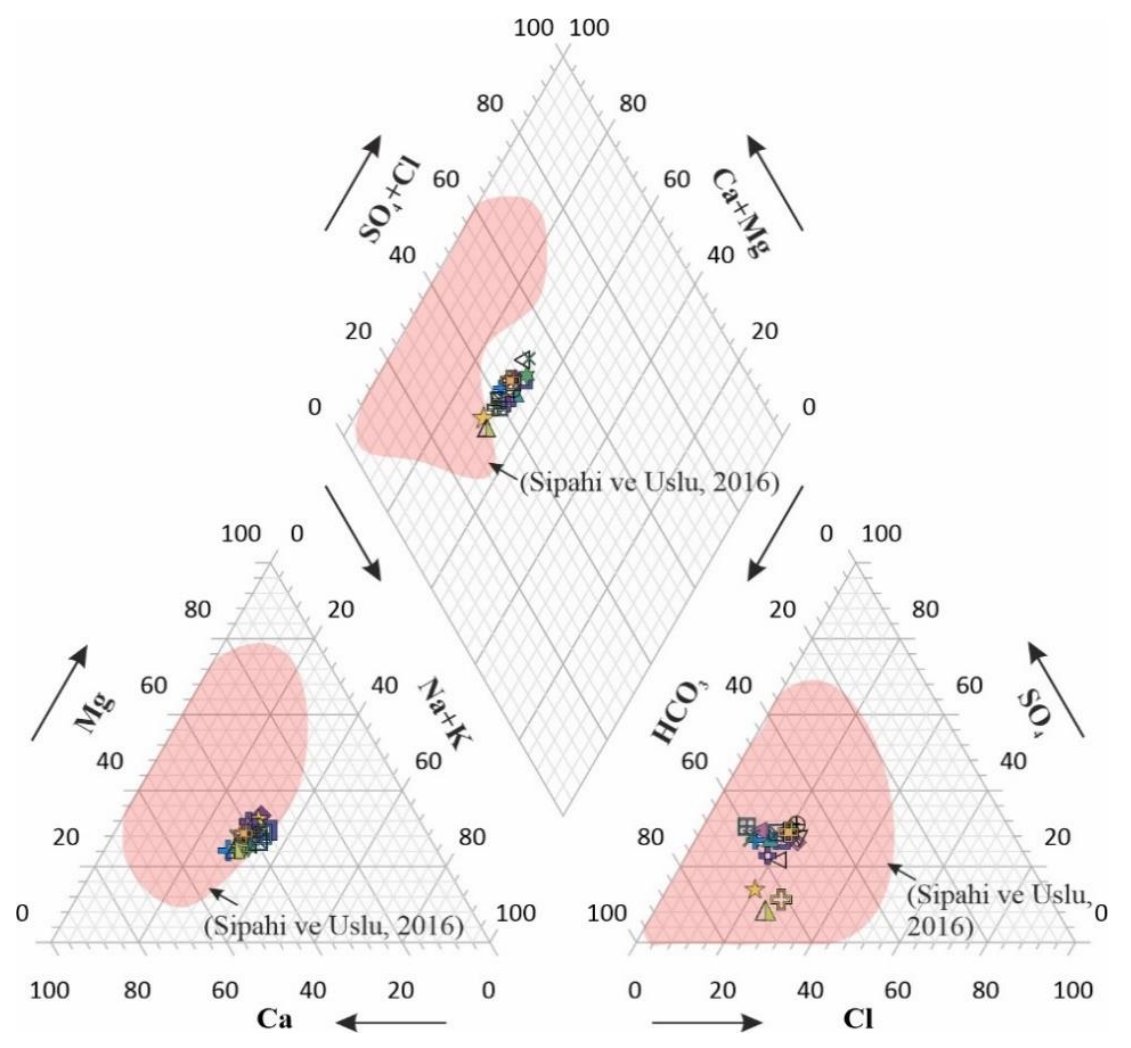

Şekil 3: Su örneklerinin Piper diyagramındaki dağılımı. Kapalı alanlar Gümüşhane il merkezi içme sularının değerlerini (Sipahi ve Uslu 2016) göstermektedir (semboller Tablo 3'deki gibidir)

Tablo 4: Klorür, sülfat ve karbonat içeriklerine göre suların sınıflandırılması (Schoeller 1955)

\begin{tabular}{lclclc}
\hline \multicolumn{2}{c}{ Klorür Sınıflaması } & \multicolumn{2}{c}{ Sülfat Sınıflaması } & \multicolumn{2}{c}{ Karbonat Sınıflaması } \\
\hline Su Sınıfı & $\begin{array}{c}\text { Klorür Miktarı } \\
(\mathbf{m e q} / \mathbf{L})\end{array}$ & Su Sınıfı & $\begin{array}{c}\text { Sülfat Miktarı } \\
(\mathbf{m e q} / \mathbf{L})\end{array}$ & $\begin{array}{c}\text { Su Sınıfı } \\
\text { Karbonat Miktarı } \\
(\mathbf{m e q} / \mathbf{L})\end{array}$ \\
\hline Hipoklorürlü sular & $>700$ & Hiposülfatlı sular & $>58$ & Hiperkarbonatlı sular & $>7$ \\
Klorotalastik sular & $420-700$ & Sülfatlı sular & $24-58$ & Normal karbonatlı sular & $2-7$ \\
Klorürce zengin sular & $140-420$ & Oligosülfatlı sular & $6-24$ & Hipokarbonatlı sular & $<2$ \\
Orta klorürlü sular & $40-140$ & Normal sülfatlı sular & $<6$ & & \\
Oligoklorürlü sular & $15-40$ & & & & \\
Normal klorürlü sular & $<15$ & & & & \\
\hline
\end{tabular}

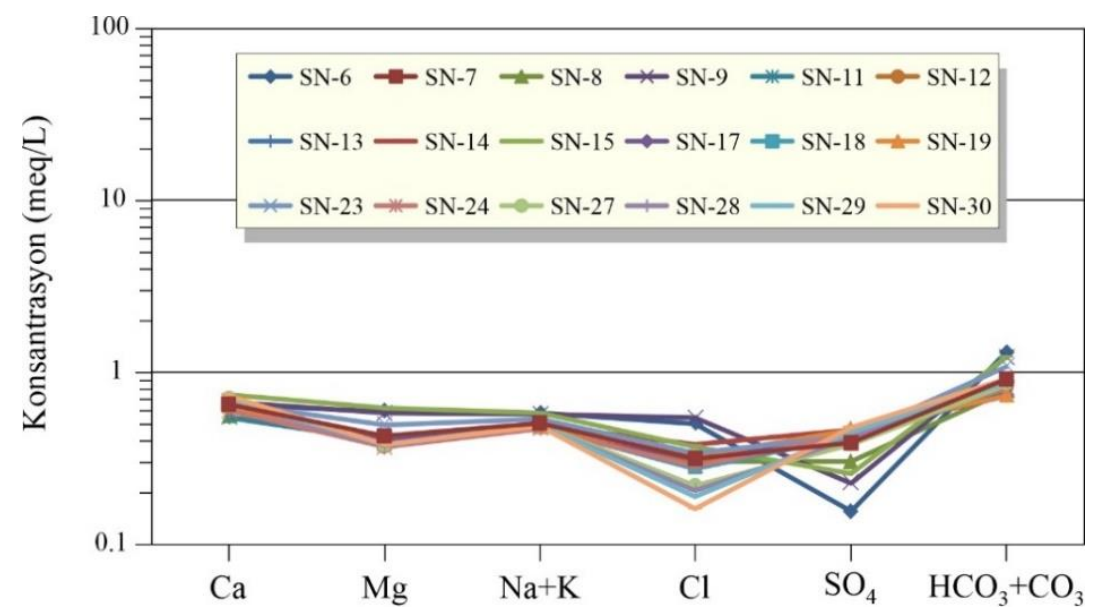

Şekil 4: Inceleme alanı örneklerinin yarı logaritmik Schoeller diyagramı 


\subsection{Hidrojeokimyasal Süreçler}

Hidrojeokimyasal süreçler, genellikle iyon değişimi, mineralizasyon, ayrışma ve çözünme gibi süreçleri kapsamakta olup, suların kimyasal analiz sonuçları kullanılmaktadır. Jeolojik oluşumlar, yeraltı suları ve kayaçlar arasında gelişen reaksiyonlar (iyonların göreceli hareketliliği, su-kayaç etkileşimi vb.) suların kalitesini ve içile bilirliğini önemli ölçüde etkilemektedir (Cederstorm 1946; Yousef vd. 2009). Kristalin kireçtaşı, dolomitik kireçtaşı, kalkgranülit gibi karbonat açısından zengin kayaçlar karbonat ayrışmasının ana kaynaklarıdır. Bu kayaçlardaki mevcut karbonatlar, sulama, yağış ve yeraltı suyu hareketi gibi olaylar sırasında çözülerek yeraltı suyu sistemine eklenebilir (örneğin, Subramani et al. 2010).

Yeraltı suyu bileşiminin akifer litolojisi ile iliş̧isini bilmek ve yeraltı sularındaki yağış, kayaç etkileşimi ve buharlaşma baskınlığı gibi kimyasal bileşenlerin kaynağını temsil etmek için bazı anyon (HCO3, $\mathrm{Cl}$ gibi) ve katyon (Na, $\mathrm{Ca}$, K gibi) değerleri kullanılmaktadır (Gibbs 1970). İnceleme alanındaki örneklerde $\mathrm{Cl} /\left(\mathrm{Cl}+\mathrm{HCO}_{3}\right)$ oranları 0.05-0.21 $(\mathrm{n}=18)$ arasında, $(\mathrm{Na}+\mathrm{K}) /(\mathrm{Na}+\mathrm{K}+\mathrm{Ca})$ oranları ise $0.28-0.51$ aralı̆ı̆ında değişim sergilemektedir. Bu değerler incelenen suların kimyasının kayaç yapıcı minerallerin kimyasal ayrışması tarafından kontrol edildiğini, dolayısıyla su-kayaç etkileşimini göstermektedir (Gibbs 1970).

\subsection{1. İyon Değişimi}

İyon değişimi, yeraltı sularındaki iyonların konsantrasyonundan sorumlu olan önemli süreçlerden biridir. Kaynak sularında iyon değişimleri kloroalkalin indeksleri (CAI) ile belirlenebilmektedir (Schoeller 1965; 1977). Bu kapsamda kullanılan kloroalkalin indeksleri I ve II aşağıda verilen (3) ve (4) no'lu eşitliklerden hesaplanmakta olup, tüm değerler meq/L cinsinden ifade edilmektedir. Örneklenen sular için hesaplanan kloroalkalin indeksleri 1 ve 2 (CAI-I ve CAI-II), iyon değişim sürecinin meydana geldiğini kuvvetle düşündürmektedir.

$\mathrm{CAI}-\mathrm{I}=[\mathrm{Cl}-(\mathrm{Na}+\mathrm{K})] / \mathrm{Cl}$

$\mathrm{CAI}-\mathrm{II}=[\mathrm{Cl}-(\mathrm{Na}+\mathrm{K})] /\left(\mathrm{SO}_{4}+\mathrm{HCO}_{3}+\mathrm{CO}_{3}+\mathrm{NO}_{3}\right)$

Bu doğrudan bir baz (katyon-anyon) değişim reaksiyonunu işaret etmekte olup, indekslerin değerleri pozitif veya negatif olabilmektedir. Yeraltı suyunda $\mathrm{Na}^{+}$veya $\mathrm{K}^{+}$ile $\mathrm{Mg}^{+2}$ veya $\mathrm{Ca}^{+2}$ arasında bir iyon değişimi söz konusu olduğunda, kloroalkalin indekslerin her ikisi de pozitif, ters iyon değişimi söz konusu olduğunda ise negatif olacaktır (Schoeller 1965;

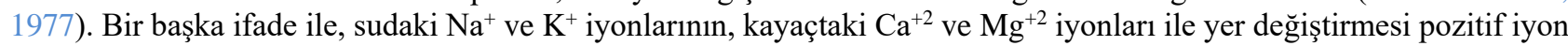

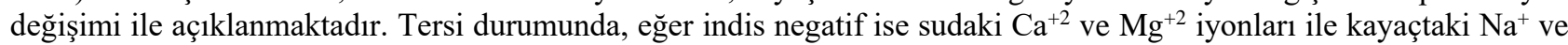
$\mathrm{K}^{+}$iyonlarının yer değiş̧tirdiği anlamına gelmektedir. İnceleme alanındaki suların CAI-I değerleri -0.05 ile -2.01 arasında değişmekte iken, CAI-II değerleri -0.02 ile -0.23 aralı̆ğında dağılım sergilemektedir (Şekil 5). Hesaplanan tüm değerler negatif olduğundan, örneklerde ters iyon değişiminin gerçekleştiğini ve kayaçların $\mathrm{Na}^{+}$ve $\mathrm{K}^{+}$iyonlarının suların $\mathrm{Mg}^{+2}$ ve $\mathrm{Ca}^{+2}$ iyonları ile yer değiştirdiğine işaret etmektedir (Şekil 5).

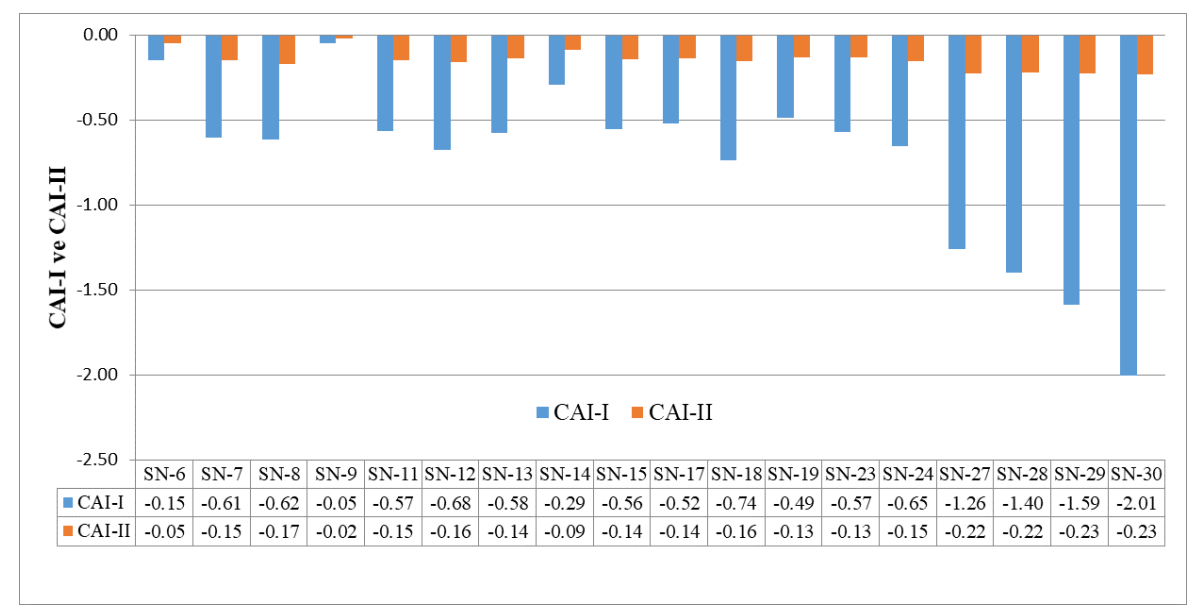

Şekil 5: Incelenen suların kloroalkalin indekslerine (CAI-I ve CAl-II) göre dağııımı

\subsubsection{Karbonat Ayrışması}

Örneklerin $\mathrm{Mg}$ ve Ca konsantrasyonları sirasıyla $4.47-29.39 \mathrm{mg} / \mathrm{L}(\mathrm{n}=18)$ ve $10.93-100.74 \mathrm{mg} / \mathrm{L}(\mathrm{n}=18)$ arasında değişmektedir. $\mathrm{SO}_{4}$ ve $\mathrm{HCO}_{3}$ konsantrasyonları ise sırasıyla $7.45-73.90 \mathrm{mg} / \mathrm{L}(\mathrm{n}=18)$ ve $44.90-381.62 \mathrm{mg} / \mathrm{L}(\mathrm{n}=18)$ arasındadır. İncelenen sularda $\mathrm{Mg}$ ve $\mathrm{Ca}$ baskın katyonları, $\mathrm{HCO}_{3}$ ise baskın anyonu teşkil etmektedir. 
İncelenen sular $\mathrm{Ca}+\mathrm{Mg}$ 'a karşı $\mathrm{SO}_{4}+\mathrm{HCO}_{3}$ grafiğine (Şekil 6a) aktarıldığında, tüm örneklerin 1:1 denge çizgisinin altında yer aldığı ve güçlü bir korelasyon $\left(\mathrm{R}^{2}=0.99\right)$ gösterdiği $\left[(\mathrm{Ca}+\mathrm{Mg})=0.9807 \times\left(\mathrm{SO}_{4}+\mathrm{HCO}_{3}\right)-0.2021\right]$ ortaya konmuştur. Elde edilen bu değerler, incelenen sularda silikat ayrışmasının etkisine işaret etmektedir.

Yeraltı sularında kalsit ve dolomitin çözünme süreçleri, $\mathrm{Ca} / \mathrm{Mg}$ oranı ile de ifade edilebilmekte olup, $\mathrm{Ca} / \mathrm{Mg}=1$ oranı dolomitin çözünmesi süreçlerini, daha yüksek oranlar ise daha fazla kalsit katkısını göstermektedir (Maya ve Loucks 1995). Ca/Mg oranının 2'den daha yüksek çıkması ise yeraltı suyuna $\mathrm{Ca}$ ve $\mathrm{Mg}$ katkısı olan silikat minerallerinin çözünmesini işaret etmektedir (Katz vd. 1998). Bu yaklaşımlar çalışma alanına uygulandığında, örneklerin $\mathrm{Ca} / \mathrm{Mg}$ oranlarının 1'in üzerinde ve 1:1 denge çizgisi çevresinde dağılım gösterdiği ve genel olarak sularda kalsit ve dolomit çözünürlüğünün etkisine işaret etmektedir (Şekil 6b). Ancak, SN-7 no'lu örnekte $\mathrm{Ca} / \mathrm{Mg}$ oranı 2'nin üzerinde $(\mathrm{Ca} / \mathrm{Mg}=$ 2.08) çıkmış olup, bu örnek için silikat minerali ayrışmasının etkin olduğunu göstermektedir.

\subsubsection{Silikat Ayrışması}

Silikat minerallerinin kimyasal reaksiyonlara katılımı yeraltı sularının jeokimyasında önemli bir rol oynamaktadır. Silikatların ayrışması genellikle uyumsuz olup, çözünmüş türlerle birlikte çeşitli katı fazlar (çoğunlukla killer) oluşturduğundan, silikatla ayrışma ürünlerinin nicelendirilmesi daha zordur (Das ve Kaur 2001). Bununla birlikte, yeraltı sularında silikat ayrışması $\mathrm{Na}+\mathrm{K}$ ile toplam katyon (TK) arasındaki oranlara göre tahmin edilebilmektedir. İncelenen sular $\mathrm{Na}+\mathrm{K}$ 'a karşı TK diyagramında, ' $\mathrm{Na}+\mathrm{K}=0.5 \times \mathrm{TK}$ ' çizgisine yakın ve üzerinde yer almıştır (Şekil $6 c$ ). Örneklerde gözlenen bu dağılım, hidrojeokimyasal süreçlerde silikat ayrışmasının katkısı ile birlikte, esas olarak $\mathrm{Na}^{+}$ve $\mathrm{K}^{+}$ iyonlarının yeraltı suyuna katkıda bulunduğunu göstermektedir (Stallard ve Edmond 1983; Sarin vd. 1989). $\mathrm{Na}^{+}$ve $\mathrm{K}^{+}$ iyonlarının kaynak sularına katkısında, bu bölgede gözlenen granitik ve volkanik kayaçlarda yaygın olan plajiyoklas (albit) ve K-feldispat (ortoklas ve mikroklin) minerallerinin ayrışmasının büyük ölçüde etkili olduğunu işaret etmektedir. Benzer şekilde, $\mathrm{Ca}+\mathrm{Mg}$ 'a karşı $\mathrm{TK}$ diyagramında, tüm örnekler ' $\mathrm{Ca}+\mathrm{Mg}=\mathrm{TK}$ ' ile ' $\mathrm{Ca}+\mathrm{Mg}=0.5 \times \mathrm{TK}$ ' çizgileri arasında pozitif yönde lineer bir dağılım sergilemektedir (Şekil $6 \mathrm{~d}$ ). $\mathrm{Ca}^{+2}$ ve $\mathrm{Mg}^{+2}$ iyonlarındaki bu artışın silikat minerallerinin ayrışmasından kaynaklanmış olabileceği düşünülmektedir. İncelenen suların $\mathrm{Ca}-\mathrm{Mg}-\mathrm{HCO}_{3}$ tipi sular sınıfında olması da silikat minerallerindeki ayrışmanın etkisini desteklemektedir.
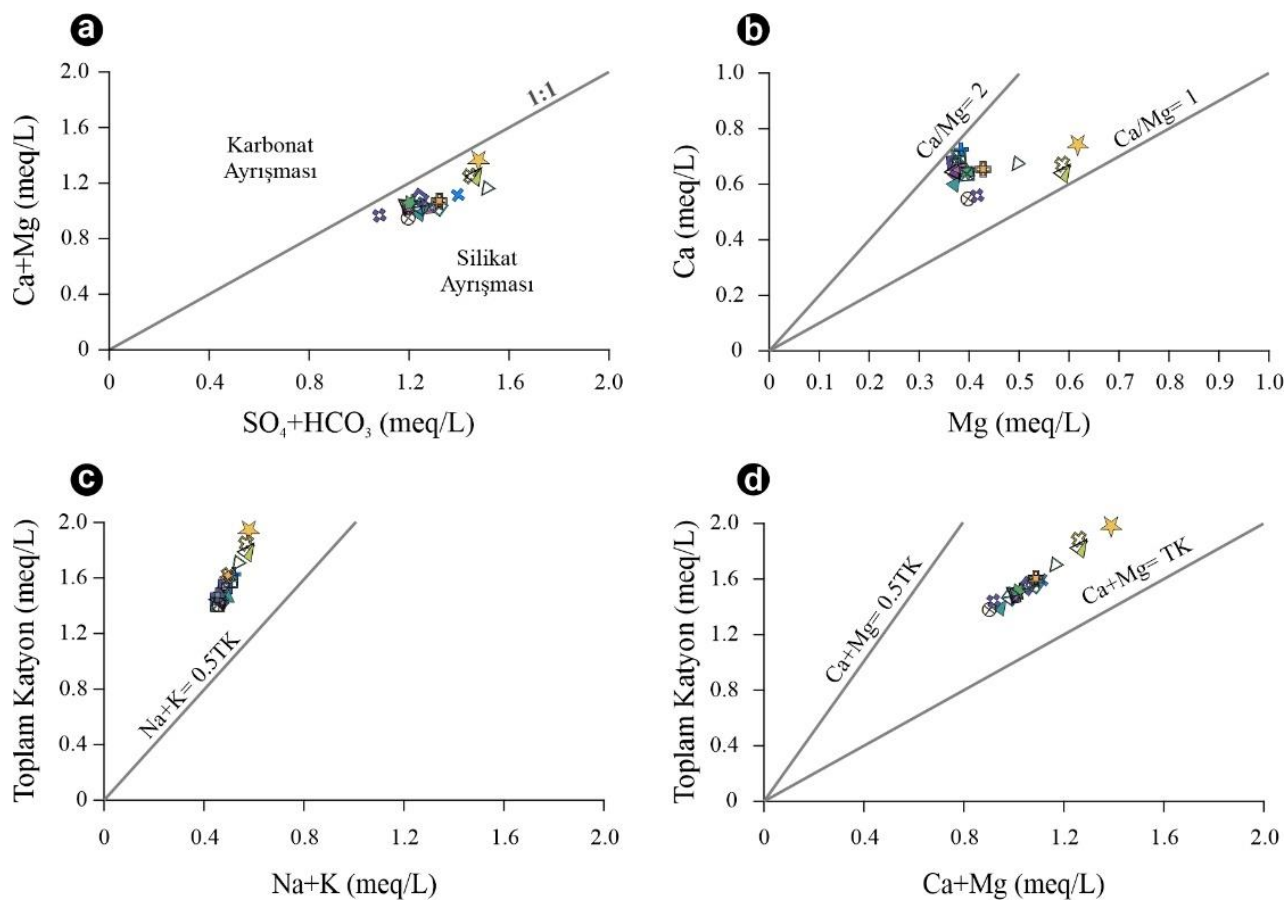

Şekil 6: Incelenen suların ayrışma diyagramları. a) $\mathrm{Ca}+\mathrm{Mg}$ 'a karşı $\mathrm{SO}_{4}+\mathrm{HCO}_{3}$ diyagramı, b) Ca-Mg diyagramı, c) toplam katyon'a karşı $\mathrm{Na}+K$ diyagramı ve d) toplam katyon'a karşı Ca+Mg diyagramı (semboller Tablo 3'deki gibidir)

\subsection{Potansiyel Toksik Element İçeriklerinin Değerlendirilmesi}

Örneklenen sular bazı önemli iz element içerikleri açısından analiz edilerek sonuçlar Tablo 5'de, çözünmüş potansiyel toksik elementlerin $(\mathrm{Cu}, \mathrm{Co}, \mathrm{Ni}, \mathrm{Pb}, \mathrm{Fe}, \mathrm{Zn})$ dağılımları ise Şekil 7'de verilmiştir. Ayrıca, örneklerdeki metal konsantrasyonlarına ilişkin analiz sonuçları İnsani Tüketim Amaçı Sular (TS 266 2005) ve Dünya Sağlık Teşkilatı İçme Suyu (WHO 2014) standartları (kabul edilebilir maksimum değerler) ile karşılaştırılmıştır. 
Tablo 5: Incelenen suların iz element analiz sonuçları

\begin{tabular}{|c|c|c|c|c|c|c|c|c|c|c|}
\hline $\begin{array}{r}\text { Parametre } \\
\text { Birimi }\end{array}$ & $\begin{array}{r}\mathrm{Fe} \\
\mu \mathrm{g} / \mathrm{L}\end{array}$ & $\begin{array}{r}\mathrm{Zn} \\
\mu \mathrm{g} / \mathrm{L}\end{array}$ & $\begin{array}{r}\mathrm{Cu} \\
\mu \mathrm{g} / \mathrm{L}\end{array}$ & $\begin{array}{r}\mathrm{Al} \\
\mu \mathrm{g} / \mathrm{L}\end{array}$ & $\begin{array}{r}\mathrm{Mn} \\
\mu \mathrm{g} / \mathrm{L}\end{array}$ & $\begin{array}{r}\mathrm{Cd} \\
\mu \mathrm{g} / \mathrm{L}\end{array}$ & $\begin{array}{r}\text { Co } \\
\mu \mathrm{g} / \mathrm{L}\end{array}$ & $\begin{array}{r}\mathrm{Ni} \\
\mu \mathrm{g} / \mathrm{L}\end{array}$ & $\begin{array}{r}\mathrm{Pb} \\
\mu \mathrm{g} / \mathrm{L}\end{array}$ & $\begin{array}{r}\mathrm{Cr} \\
\mu \mathrm{g} / \mathrm{L}\end{array}$ \\
\hline \multicolumn{11}{|l|}{ Örnek } \\
\hline SN-6 & 68.3 & 249.4 & 25.7 & 32.7 & tsa & tsa & tsa & 10.3 & tsa & tsa \\
\hline $\mathrm{SN}-7$ & 59.8 & 262.9 & 28.1 & 14.1 & tsa & tsa & tsa & tsa & 23.5 & tsa \\
\hline $\mathrm{SN}-8$ & 60.4 & 267.0 & 20.4 & 17.3 & tsa & tsa & tsa & tsa & 16.1 & tsa \\
\hline SN-9 & 61.5 & 272.4 & 22.0 & 42.2 & tsa & tsa & tsa & 12.1 & 24.6 & tsa \\
\hline SN-11 & 63.7 & 264.7 & 24.9 & 17.7 & tsa & tsa & 81.0 & tsa & tsa & tsa \\
\hline SN-12 & 65.6 & 256.9 & 25.5 & 15.1 & tsa & tsa & 128.9 & tsa & tsa & tsa \\
\hline SN-13 & 66.7 & 263.7 & 25.8 & 14.0 & tsa & tsa & 123.5 & tsa & tsa & tsa \\
\hline SN-14 & 66.1 & 259.5 & 25.8 & tsa & tsa & tsa & 106.2 & tsa & tsa & tsa \\
\hline SN-15 & 67.0 & 260.1 & 30.1 & 23.7 & tsa & tsa & 87.8 & tsa & tsa & tsa \\
\hline SN-17 & 96.2 & 249.7 & 27.1 & tsa & tsa & tsa & 66.5 & tsa & tsa & tsa \\
\hline SN-18 & 72.2 & 240.3 & 26.6 & tsa & tsa & tsa & 50.2 & tsa & tsa & tsa \\
\hline SN-19 & 72.2 & 233.5 & 26.3 & tsa & tsa & tsa & 50.9 & tsa & tsa & tsa \\
\hline $\mathrm{SN}-23$ & 68.6 & 227.0 & 28.0 & 11.0 & tsa & tsa & tsa & tsa & tsa & tsa \\
\hline $\mathrm{SN}-24$ & 64.8 & 230.0 & 53.8 & 16.1 & tsa & tsa & tsa & tsa & tsa & tsa \\
\hline $\mathrm{SN}-27$ & 67.2 & 182.6 & 26.0 & 10.6 & tsa & tsa & 82.3 & tsa & tsa & tsa \\
\hline $\mathrm{SN}-28$ & 66.2 & 166.1 & 27.3 & 11.0 & tsa & tsa & 115.2 & tsa & tsa & tsa \\
\hline SN-29 & 66.9 & 168.0 & 31.7 & 10.3 & tsa & tsa & 97.6 & tsa & tsa & tsa \\
\hline SN-30 & 64.7 & 134.0 & 44.0 & tsa & tsa & tsa & 83.1 & tsa & tsa & tsa \\
\hline TISSS $^{1}$ & $<200$ & $<5000$ & $<2000$ & $<200$ & $<50$ & $<5$ & $\leq 10$ & $<20$ & $<10$ & $<50$ \\
\hline DSTİSS ${ }^{2}$ & $<300$ & $<15000$ & $<2000$ & $<200$ & $<100$ & $<3$ & - & $<20$ & $<10$ & $<50$ \\
\hline
\end{tabular}

${ }^{1}$ TİSS (TS 266, 2005): Türkiye İçme Suyu Standardı, ${ }^{2}$ DSTISS (WHO 2014): Dünya Sağlık Teşkilatı İçme Suyu Standardı (izin verilebilir sınırın üzerinde çıkan sonuçlar koyu gösterilmiştir). tsa: tayin sınırı altında.

Doğada bulunan sularda majör iyonlar dışında farklı yollarla (asit maden/kaya drenajı, asit yağmurları, endüstriyel atıklar vb.) çözünerek geçen yüksek miktarlarda metal element ( $\mathrm{Fe}, \mathrm{Mn}, \mathrm{Cr}, \mathrm{Cd}, \mathrm{Al}, \mathrm{Zn}, \mathrm{Cu}, \mathrm{Co}, \mathrm{Ni}, \mathrm{Pb}$ vb.) konsantrasyonları canlı yaşamı ve çevresel etkiler açısından büyük problemlere yol açabilmektedir. Doğal sularda Fe dışındaki ağır metaller 1 ppm'den daha düşük konsantrasyonlarda bulunmakta olup (Freeze ve Cherry 1979), bu elementlerden bazıları sularda istenmeyen metalik bir tad ve bulanıklığa sebep olmakta iken, $\mathrm{Cu}, \mathrm{Pb}$ gibi toksik elementler sağlık açısından ciddî problemler teşkil etmektedir (Dündar ve Aslan 2005).

Fe ve Mn doğada bulunan ve yer kabuğunda doğal olarak oluşmuş en yaygın metal grubu elementlerdendir. Fe elementi kayaçlarda özellikle piroksen, amfibol, biyotit, granat, magnetit, pirit gibi minerallerin ayrışması sonucu yaygın olarak $\mathrm{Fe}^{+2}$ iyonu, asit çözeltilerde ise genellikle $\mathrm{Fe}^{+3}$ iyonu şeklinde açığa çıkmaktadır. Bu metaller, canlıların bünyesinde yoğunlaştığında birçok kronik ve dejeneratif hastalıklara neden olabilmektedir (Zaloğlu 2001; Özbolat ve Tuli 2016). İncelenen suların Fe içerikleri 59.84-96.21 $\mu \mathrm{g} / \mathrm{L}$ (ortalama: 67.7, n= 18) arasında değişmektedir. TS 266' da içme sularının Fe değerinin $200 \mu \mathrm{g} / \mathrm{L}$ 'den az olması gerektiği belirtilmiş olup, incelenen suların suların Fe değerleri kabul edilebilir sınırlar içerisindedir. Örneklerin Mn konsantrasyonları ise ölçüm sınırı (<12.5 $\mu \mathrm{g} / \mathrm{L})$ altındadır.

$\mathrm{Cu}$ elementi kayaçlarda pirit, kalkopirit, bornit, malahit, azurit gibi minerallerde yaygın olarak bulunmakla birlikte, doğal sularda ise genellikle eser miktarda (50 $\mu \mathrm{g} / \mathrm{L}$ 'ye kadar) bulunabilmektedir (McNeely vd. 1979). Bununla birlikte belirli bir seviyede $\mathrm{Cu}$ elementi bulunması, canlı yaşamı açısından önem arz etmektedir. Ancak belirli oranların üzerinde olması, gerek canlı yaşamı açısından, gerekse çevresel etkileri bakımından ciddîproblemler ortaya çıkaracaktır. İçme sularında $\mathrm{Cu}$ miktarının yüksek olması merkezi sinir sistemi bozuklukları nedeniyle mukozal iltihaplanma, damar hastalığı, karaciğer ve böbrek hastalıklarına ve depresyona neden olabilmektedir (Güler ve Çobanoğlu 1994; Baysal 1999; Soylak ve Doğan 2000). İncelenen suların Cu değeri 20.40-53.80 $\mu \mathrm{g} / \mathrm{L}$ (ortalama: 28.8, n=18) aralı̆̆ında olup, TS 266 'da izin verilebilir en üst değerin $(<2000 \mu \mathrm{g} / \mathrm{L})$ oldukça altındadır.

Co, genellikle volkanik kayaçlarda bulunmakla birlikte, vücutta aşırı birikme sonucu kanser, akciğer ve kalp hasarı ve işlev bozukluğu ile kolesterol, yağ seviyesi ve kan şekeri gibi rahatsızlıklara neden olabilmektedir (Atabey 2005). İnceleme alanı su örneklerinin Co içerikleri SN-6, SN-7, SN-8, SN-9, SN-23 ve SN-24 nolu örneklerde TS 266'da izin verilebilir sınır olan $10 \mu \mathrm{g} / \mathrm{L}$ 'nin altında iken, diğer örneklerde bu değerin üzerinde dağılım sergilemiştir. Co içeriğinin, çalışma alanı ve yakın çevresinde yaygın gözlenen volkanik kayaçların ve maden yataklarının varlığından etkilenmiş olabileceği düşünülmektedir. 
Ni bileşikleri pratik olarak suda çözünmeyip, sulardaki doğal Ni miktarı çok düşüktür. Genellikle bazik ve ultrabazik kayaçlarda gözlenmektedir. Ni elementi vücuda solunum, içilen su ve/veya beslenme yoluyla alınmaktadır. Ni toksik bir element olmadığından, gıda ve sularda belirli bir miktarda bulunmasının ciddi bir sağlık problemine yol açacağı düşünülmemektedir (Güler ve Çobanoğlu 1994). İçme ve kullanma sularında izin verilebilir maksimum Ni değeri <20 $\mu \mathrm{g} / \mathrm{L}$ olup, incelenen suların Ni değerleri $20 \mu \mathrm{g} / \mathrm{L}$ 'nin altındadır. Dolayısıyla, Ni içeriklerinin TS 266'da izin verilebilir aralıklara uygun olduğu görülmektedir.

Zn, doğada çoğunlukla bazik ve ultrabazik kayaçlarda ve pek çok mineralde bulunmakta olup, içme suyu ile de vücuda alınabilmektedir. Ancak, insan vücudunda Zn elementi için depo sisteminin olmayışı, bu elementin vücutta artması ile ciddi sağlık problemleri meydana getireceği gibi, suyun tadını ve görünüşünü de değiştirecektir (Baysal 1999). İncelenen suların $\mathrm{Zn}$ değeri 134.03-272.35 $\mu \mathrm{g} / \mathrm{L}$ (ortalama: 232.7; $\mathrm{n}=18$ ) aralığında olup, TS-266' da izin verilebilir maksimum değerin $(<5000 \mu \mathrm{g} / \mathrm{L})$ oldukça altındadır. Bununla birlikte, örneklerin Zn içeriğinin sınır değerin $(100 \mu \mathrm{g} / \mathrm{L})$ üzerinde dağılım sergilediği ve çalışma alanında gözlenen alterasyon alanlarında sülfürlü minerallerin yıkanması sonucu açığa çıkan asit maden sularından kaynaklı olabileceği düşünülmektedir.

Yüksek oranda toksik bir element olan $\mathrm{Cd}$, doğada genelde $\mathrm{Zn}, \mathrm{Cu}$ ve $\mathrm{Pb}$ elementleri ile birlikte ince partiküller halinde bulunur ve çoğunlukla endüstriyel atıklardan itibaren sulara karışır. Cd ve bileşikleri kanserojenik olup, baş ağrısı, susuzluk hissi, bronşit, sinirlilik, anemi, böbrek taşı gibi rahatsızlıklara neden olabilmektedir (Güler ve Çobanoğlu 1994). İnceleme alanındaki suların Cd değeri cihaz ölçüm sınırı altında olup, TS 266'ya göre izin verilebilir sınırlar $(<10 \mu \mathrm{g} / \mathrm{L})$ içerisinde yer aldığı kabul edilmektedir.

Yerkabuğunun doğal bir bileşeni olan ve doğada en çok $\mathrm{PbS}, \mathrm{PbZn}$ vb. bileşikler halinde bulunan $\mathrm{Pb}$ elementi, $\mathrm{Pb}$ içeren bileşiklerin çözünürlügünün düşük olması ve düşük mobilitesinden dolayı akarsu ve yeraltı suyu gibi doğal sularda birkaç $\mu \mathrm{g} / \mathrm{L}$ 'den $20 \mu \mathrm{g} / \mathrm{L}$ 'ye kadar değişen oranlarda bulunur (Matthes 1982). İnsan vücudunda çok farklı (içme suyu, yiyecek, sigara, toz, toprak, hava, boya, egzoz dumanı vb.) yollardan alınmakta olup, toksik etkisi bulunmaktadır. İncelenen birkaç örneğin (SN-7, SN-8 ve SN-9) Pb konsantrasyonlarının, izin verilebilir değer olan $\leq 10 \mu \mathrm{g} / \mathrm{L}$ 'nin üzerinde oldukları görülmektedir. Diğer örnekler ise ölçüm sınırı altında kalmaktadır.

Bir diğer ağır metal olan $\mathrm{Cr}$ elementinin $\mathrm{Cr}^{+6}$ iyonu kanserojen özellikte olup, içme sularında bulunması ciddi sağlık problemlerine neden olabilmektedir (Özbolat ve Tuli 2016). Sularda Cr elementinin bulunması su kirliliğini işaret etmektedir. İçme sularının kullanılabilmesi için $\mathrm{Cr}$ konsantrasyonunun $<50 \mu \mathrm{g} / \mathrm{L}$ olması istenmektedir. İncelenen tüm suların $\mathrm{Cr}$ değerleri tayin sınırı altında çıkmıştır. $\mathrm{Bu}$ dağılımın, $\mathrm{Cr}$ elementinin en önemli kaynak kayaçlarından olan ultramafitlerin inceleme alanı ve yakın civarında gözlenmemesinden kaynaklanmış olabileceği düşünülmektedir.

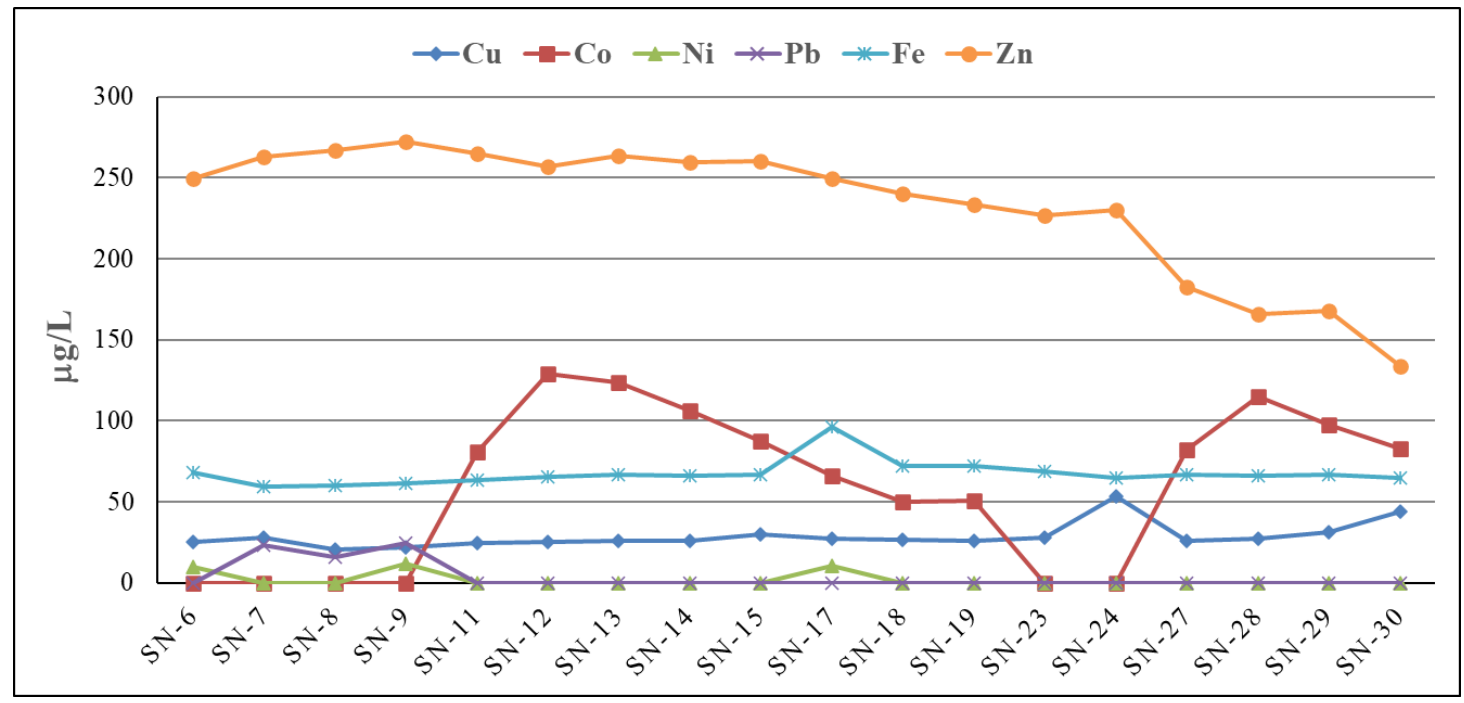

Şekil 7: Inceleme alanındaki suların potansiyel toksik element (Fe, Zn, Cu, Co ve Pb) içeriklerinin karşılaştırılmış dağılımı

\subsection{Suların İçilebilirliği ve Kalitesi}

İnceleme alanındaki suların su kalitesinin değerlendirilmesinde TSE (TS 266 2005) ve Dünya Sağlık Örgütü (WHO 2014) standartları kullanılmıştır. Bunun yanı sıra, inceleme alanındaki kaynak sularının içilebilirliğini belirlemek için Schoeller içilebilme diyagramı kullanılmıştır (Şekil 8).

Suların içilebilirliğinin değerlendirilmesinde en önemli parametrelerden biri olan Cl iyonu için izin verilebilir değerler TS 266'e göre 30-250 mg/L ve WHO’ya göre <250 mg/L'dir. İnceleme alanı örneklerinde Cl değerleri 5.72-19.26 mg/L $(\mathrm{n}=18)$ olup, izin verilebilir sınırlar içerisindedir. $\mathrm{SO}_{4}$ ise genellikle pirit, anhidrit ve jips gibi sülfürlü minerallerin oksidasyonu sonucu oluşmakta ve içme sularına doğal yollarla karışan önemli anyonlardan birini teşkil etmektedir. 
Gerek TS 266, gerekse WHO’ya göre izin verilebilir $\mathrm{SO}_{4}$ miktarı $<250 \mathrm{mg} / \mathrm{L}$ 'dir. Çalışma alanı örneklerinde bu değerler 7.45-22.82 mg/L $(n=18)$ arasında değişmekte olup, kabul edilebilir sınırlar içerisindedir. Na elementi doğal suların bileşiminde en yaygın olarak bulunan alkali metaldir ve genel olarak plajiyoklas ayrışması ve killeşme gibi süreçlerle sulara karışmaktadır. İncelenen örneklerin $\mathrm{Na}$ değeri 10.70-12.86 mg/L (n=18) arasında değişmektedir. İncelenen sularda $\mathrm{Na}^{+}$değerleri 200 mg/L'den düşük olup, TS 266 ve WHO’ya göre kabul edilebilir sınırlar içerisindedir.

Kaynak sularının içilebilirliğinin tayin edildiği Schoeller diyagramına göre, örneklerin elektriksel iletkenlik, sertlik, $\mathrm{Na}, \mathrm{Cl}$ ve $\mathrm{SO}_{4}$ parametreleri açısından ‘çok iyi kaliteli sular' sınıfında yer aldığı belirlenmiştir (Şekil 8). Bununla birlikte, su kirliliği ve kalitesini ortaya koymak amacıyla, elde edilen sonuçlar kıta içi su kalite standartları (URL-2 2012) ile bazı fizikokimyasal parametreler ( $\mathrm{pH}$, ÖEİ) ve iz elementler ( $\mathrm{Fe}, \mathrm{Zn}, \mathrm{Cu}, \mathrm{Al}, \mathrm{Mn}, \mathrm{Cd}, \mathrm{Co}, \mathrm{Ni}, \mathrm{Pb}, \mathrm{Cr}$ ) açısından karşılaştırılmıştır (Tablo 6). Örneklerin büyük bir çoğunluğu su kalitesi açısından I. ve II. sınıf kaliteyi yansıtırken, bazı örneklerde (SN-24, SN-27, SN-28, SN-29 ve SN-30) birkaç parametre (pH, Zn, Cu, Co ve Pb) açısından kirlilik belirtisi göstermektedir. Kaynak sularının, özellikle fay zonu ve/veya maden yatağı gibi alanlarda meydana gelen su-kayaç etkileşimi ile bazı metal element konsantrasyonlarında artı̧̧ gözlenebilmektedir. Nitekim, söz konusu örneklerde kirletici olarak rol oynayan elementlerin başında $\mathrm{Zn}, \mathrm{Cu}, \mathrm{Co}$ ve $\mathrm{Pb}$ gelmekte olup, bu durumun, özellikle bölgede gözlenen maden yatakları, örneğin Gümüşdamla Yayla $\mathrm{Pb}-\mathrm{Zn} \pm \mathrm{Au} \pm \mathrm{Ag}$ (Akbulut vd. 2014) ve Ünlüpınar Pb-Zn $\pm \mathrm{Au}$ (Akbulut vd. 2015) cevherleşmeleri ile ilişkili olabileceği düşünülmektedir.

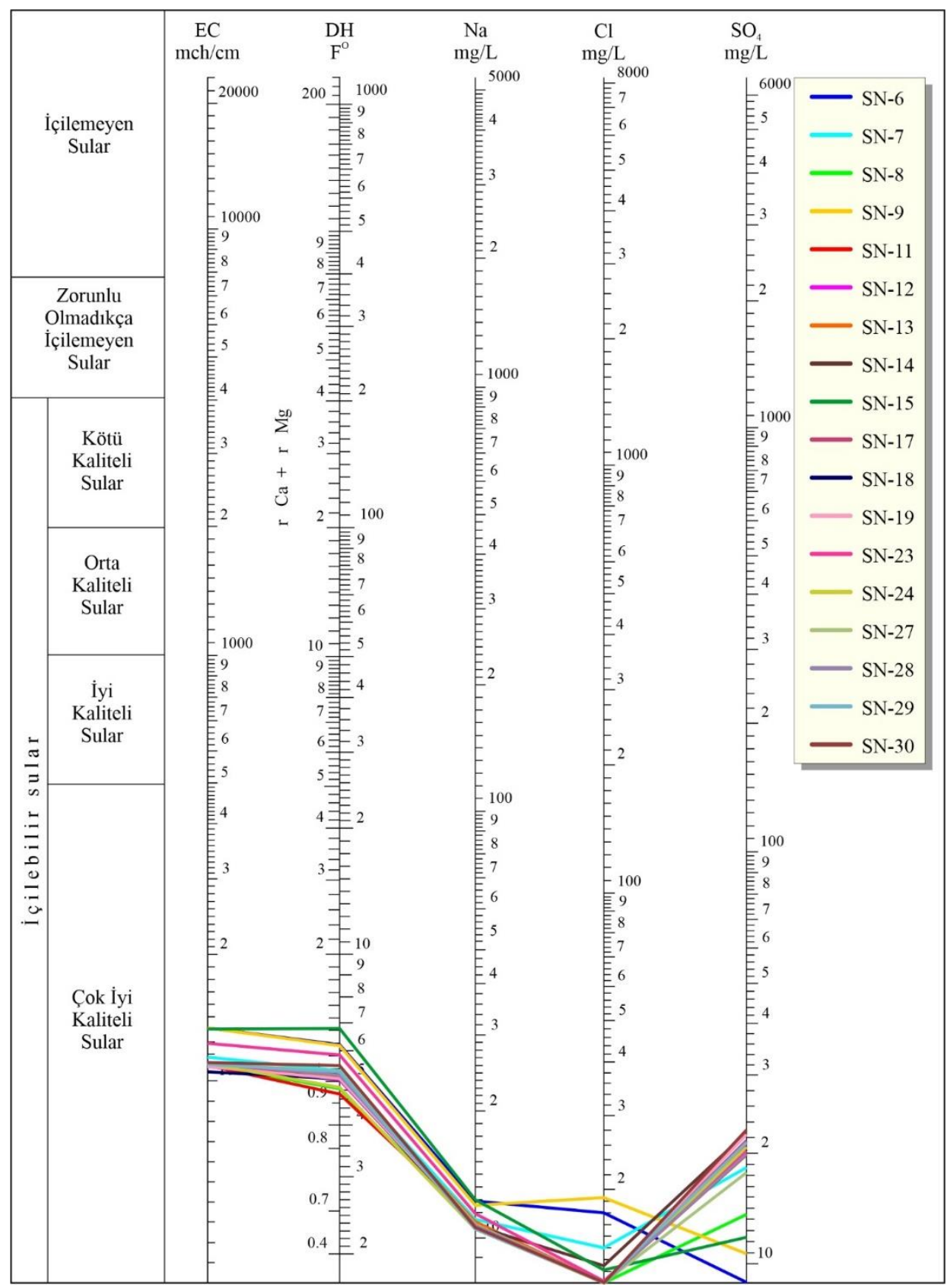

Şekil 8: Inceleme alanı su örneklerinin Schoeller içilebilirlik diyagramındaki konumları 
Tablo 6: Inceleme alanındaki örneklerin bazı fizikokimyasal parametreler ve iz elementler (metaller) açısından su kalite sınıfları

\begin{tabular}{|c|c|c|c|}
\hline Örnek & Alındığı Yer & Su Kalite Parametreleri & Su Kalite Sinıfı \\
\hline \multirow{2}{*}{ SN-6 } & \multirow{2}{*}{ Mertekli Mahallesi Merkez Çeşmesi } & $\mathrm{pH}, \mathrm{ÖEI}, \mathrm{Fe}, \mathrm{Al}, \mathrm{Mn}, \mathrm{Cd}, \mathrm{Co}, \mathrm{Ni}, \mathrm{Pb}, \mathrm{Cr}$ & I \\
\hline & & $\mathrm{Zn}, \mathrm{Cu}$ & II \\
\hline \multirow{2}{*}{ SN-7 } & \multirow{2}{*}{ Mertekli Mahallesi Meydan Çeşmesi } & pH, ÖEİ, $\mathrm{Fe}, \mathrm{Al}, \mathrm{Mn}, \mathrm{Cd}, \mathrm{Co}, \mathrm{Ni}, \mathrm{Cr}$ & I \\
\hline & & $\mathrm{Zn}, \mathrm{Cu},(\mathrm{Pb})$ & II, (III) \\
\hline \multirow{2}{*}{ SN-8 } & \multirow{2}{*}{ Meydan Çeşmesi } & $\mathrm{pH}, \mathrm{ÖEI}, \mathrm{Fe}, \mathrm{Al}, \mathrm{Mn}, \mathrm{Cd}, \mathrm{Co}, \mathrm{Ni}, \mathrm{Cr}$ & I \\
\hline & & $\mathrm{Zn}, \mathrm{Cu}, \mathrm{Pb}$ & II \\
\hline \multirow{2}{*}{ SN-9 } & \multirow{2}{*}{ Çeşme (isimsiz) } & pH, ÖEİ, $\mathrm{Fe}, \mathrm{Al}, \mathrm{Mn}, \mathrm{Cd}, \mathrm{Co}, \mathrm{Ni}, \mathrm{Cr}$ & I \\
\hline & & $\mathrm{Zn}, \mathrm{Cu},(\mathrm{Pb})$ & II, (III) \\
\hline \multirow{2}{*}{ SN-11 } & \multirow{2}{*}{ Çeşme (isimsiz) } & pH, ÖEİ, Fe, Al, Mn, Cd, Ni, Pb, Cr & I \\
\hline & & $\mathrm{Zn}, \mathrm{Cu},(\mathrm{Co})$ & II, (III) \\
\hline \multirow{2}{*}{ SN-12 } & \multirow{2}{*}{ Çeşme (isimsiz) } & pH, ÖEİ, Fe, Al, Mn, Cd, Ni, Pb, Cr & I \\
\hline & & $\mathrm{Zn}, \mathrm{Cu},(\mathrm{Co})$ & II, (III) \\
\hline \multirow{2}{*}{ SN-13 } & \multirow{2}{*}{ Merkez Çarşı Camii Şadırvanı } & pH, ÖEİ, $\mathrm{Fe}, \mathrm{Al}, \mathrm{Mn}, \mathrm{Cd}, \mathrm{Ni}, \mathrm{Pb}, \mathrm{Cr}$ & I \\
\hline & & $\mathrm{Zn}, \mathrm{Cu},(\mathrm{Co})$ & II, (III) \\
\hline \multirow{2}{*}{ SN-14 } & \multirow{2}{*}{ Tekke Camii Şadırvanı } & pH, ÖEİ, Fe, Al, Mn, Cd, Ni, Pb, Cr & I \\
\hline & & $\mathrm{Zn}, \mathrm{Cu},(\mathrm{Co})$ & II, (III) \\
\hline \multirow{2}{*}{ SN-15 } & \multirow{2}{*}{ Esentepe Camii Şadırvanı } & pH, ÖEİ, Fe, Al, Mn, Cd, Ni, Pb, Cr & I \\
\hline & & $\mathrm{Zn}, \mathrm{Cu},(\mathrm{Co})$ & II, (III) \\
\hline \multirow{2}{*}{ SN-17 } & \multirow{2}{*}{ Şeyhi Şirani Çeşmesi } & pH, ÖEİ, $\mathrm{Fe}, \mathrm{Al}, \mathrm{Mn}, \mathrm{Cd}, \mathrm{Ni}, \mathrm{Pb}, \mathrm{Cr}$ & I \\
\hline & & $\mathrm{Zn}, \mathrm{Cu},(\mathrm{Co})$ & II, (III) \\
\hline \multirow{2}{*}{ SN-18 } & \multirow{2}{*}{ Tekke Gözesi } & pH, ÖEİ, $\mathrm{Fe}, \mathrm{Al}, \mathrm{Mn}, \mathrm{Cd}, \mathrm{Ni}, \mathrm{Pb}, \mathrm{Cr}$ & I \\
\hline & & $\mathrm{Zn}, \mathrm{Cu},(\mathrm{Co})$ & II, (III) \\
\hline \multirow{2}{*}{ SN-19 } & \multirow{2}{*}{ Osman Keleş Hayratı } & pH, ÖEİ, Fe, Al, Mn, Cd, Ni, Pb, Cr & I \\
\hline & & $\mathrm{Zn}, \mathrm{Cu},(\mathrm{Co})$ & II, (III) \\
\hline \multirow{2}{*}{$\mathrm{SN}-23$} & \multirow{2}{*}{ Çeşme (isimsiz) } & pH, ÖEİ, Fe, Al, Cd, Co, Cr, Mn, Pb, Ni & I \\
\hline & & $\mathrm{Zn}, \mathrm{Cu}$ & II \\
\hline \multirow{2}{*}{$\mathrm{SN}-24$} & \multirow{2}{*}{ Çeşme (isimsiz) } & pH, ÖEİ, Fe, Al, Mn, Cd, Co, Ni, Cr, Pb & I \\
\hline & & $\mathrm{Zn},(\mathrm{Cu})$ & II, (III) \\
\hline \multirow{2}{*}{ SN-27 } & Göze (isimsiz) & ÖEİ, $\mathrm{Fe}, \mathrm{Zn}, \mathrm{Al}, \mathrm{Mn}, \mathrm{Cd}, \mathrm{Ni}, \mathrm{Pb}, \mathrm{Cr}$ & I \\
\hline & & $\mathrm{Cu},(\mathrm{pH}, \mathrm{Co})$ & II, (III) \\
\hline SN-28 & Cesme (isimsiz) & ÖEİ, $\mathrm{Fe}, \mathrm{Zn}, \mathrm{Al}, \mathrm{Mn}, \mathrm{Cd}, \mathrm{Ni}, \mathrm{Pb}, \mathrm{Cr}$ & I \\
\hline 年 & दुo & $\mathrm{Cu},(\mathrm{pH}, \mathrm{Co})$ & II, (III) \\
\hline SN-29 & Cesme (isimsiz) & ÖEİ, Fe, Zn, Al, Mn, Cd, Ni, Pb, Cr & $\mathrm{I}$ \\
\hline & & $\mathrm{Cu},(\mathrm{Co}),[\mathrm{pH}]$ & II, (III), [IV] \\
\hline SN-30 & Göze (isimsiz) & ÖEİ, Fe, Zn, Al, Mn, Cd, Ni, Pb, Cr & I \\
\hline & & $\mathrm{Cu},(\mathrm{Co}),[\mathrm{pH}]$ & II, (III), [IV] \\
\hline
\end{tabular}

\section{Sonuçlar ve Öneriler}

Bu çalı̧̧ma, Şiran (Gümüşhane, KD Türkiye) ilçe merkezi su kaynaklarının hidrojeokimyasal karakteristiklerini ortaya koyan ilk çalışma niteliğinde olup, ayrıca suların kirlilik parametreleri, içilebilirliği ve su kalitesi de irdelenmiştir. İnceleme alanında baskın litolojiyi çakıltaşı, kumtaşı, marn, kumlu kireçtaşı ve şeyl ardışımından oluşan Eosen yaşlı Kelkit Formasyonu ile alüvyon/yamaç molozu oluşturmaktadır. Su örnekleri genel olarak alüvyon üzerinde yer alan kaynaklardan derlenmiştir. Alüvyon ve yamaç molozu çalışma alanındaki taneli gözenekli serbest akifer ortamını temsil etmektedir. 
İncelenen sular pH değerlerine göre çoğunlukla (15 örnek) asidik, çok az bir kısmı (3 örnek) ise az alkali özellik göstermektedir. Yerüstü Su Kalitesi Yönetmeliği Su Kalite sınıflandırmasına (URL-2 2012) göre, pH değerleri açısından 14 örnek I. sınıf su kalitesini, 4 örnek ise III. ve IV. sınıf su kalitesini yansıtmaktadır. TS 266 ve WHO içme suyu standartlarına göre 2 örnek dışındaki tüm sular içilebilir sınırlar içerisinde yer almaktadır. Suların ÖEİ değerleri TS 266 ile WHO içme-kullanma suları standartlarına göre I. sınıf su kalitesini yansıtmaktadır. İnceleme alanındaki suların büyük bir çoğunluğunun (15 örnek) yumuşak su, az bir kısmının ise orta-sert su (3 örnek) olduğu belirlenmiş, sertlik açısından suların içilebilir özellikte olduğu ortaya konmuştur. Sular düşük $\mathrm{SO}_{4}$ ve $\mathrm{Cl}$ içeren $\mathrm{Ca}-\mathrm{Mg}-\mathrm{HCO}_{3}$ tipli sular sınıfında yer almış ve genel olarak karbonatlı $(\mathrm{Ca}+\mathrm{Mg}>\mathrm{Na}+\mathrm{K})$ sular özelliği gösteren tüm örneklerin zayıf asit köklerinin, güçlü asit köklerinden $\left(\mathrm{HCO}_{3}>\mathrm{SO}_{4}+\mathrm{Cl}\right)$ daha fazla olduğu sonucuna varılmıştır. İncelenen örnekler $\mathrm{Cl}$ içerikleri bakımından 'normal klorürlü sular', sülfat konsantrasyonları açısından ise 'normal sülfatlı sular' özelliğindedir. Karbonat miktarı açısından ise genellikle 'hipokarbonatlı sular' özelliğindedir. Majör anyon konsantrasyonları bakımından $\mathrm{Ca}>\mathrm{Na}>\mathrm{Mg}>\mathrm{K}$ ve $\mathrm{HCO}_{3}>\mathrm{SO}_{4}>\mathrm{Cl}$ sıralaması gösteren örnekler, Schoeller içilebilirlik sınıflamasına göre karbonatlı kayaçlardan gelen sular dağılımına benzer yönelim göstermiştir. Örneklerde $\mathrm{Cl} /\left(\mathrm{Cl}+\mathrm{HCO}_{3}\right)$ ve $(\mathrm{Na}+\mathrm{K}) /(\mathrm{Na}+\mathrm{K}+\mathrm{Ca})$ oranları, incelenen su kaynaklarının kimyasının kayaç yapıcı minerallerin kimyasal ayrışması tarafından kontrol edildiğini, dolayısıyla su-kayaç etkileşimine işaret etmiştir. İncelenen sularda ters iyon değişiminin gerçekleştiği, dolayısıyla kayaçların $\mathrm{Na}^{+}$ve $\mathrm{K}^{+}$ iyonlarının suların $\mathrm{Mg}^{+2}$ ve $\mathrm{Ca}^{+2}$ iyonları ile yer değiştirdiği ortaya konmuştur. $\mathrm{Mg}$ ve Ca baskın katyonları, $\mathrm{HCO}_{3}$ ise baskın anyonu teşkil etmiş ve $\mathrm{Ca}+\mathrm{Mg}$ 'a karşı $\mathrm{SO}_{4}+\mathrm{HCO}_{3}$ oranları sularda silikat ayrışmasının etkisine işaret etmiştir. Sularda $\mathrm{Na}+\mathrm{K}$ ve toplam katyon oranları, hidrojeokimyasal süreçlerde silikat ayrışmasının katkısı ile birlikte, esas olarak $\mathrm{Na}$ ve K iyonlarının yeraltı suyuna katkıda bulunduğunu göstermiştir. Örneklerin çözünmüş $\mathrm{Fe}, \mathrm{Al}, \mathrm{Mn}, \mathrm{Cd}, \mathrm{Ni}$ ve $\mathrm{Cr}$ element içerikleri bakımından TS 266 ve WHO’ya göre kabul edilebilir sınırlar içerisinde dağılım gösterdiği ve I. sınıf su kalitesini yansıttığı, buna karşılık bazı örneklerde ise birkaç parametre $(\mathrm{Zn}, \mathrm{Cu}, \mathrm{Co}$ ve $\mathrm{Pb})$ açısından kirlilik belirtisi gösterdiği belirlenmiş olup, bu suların insani tüketim amaçlı kullanılmaması önerilmekte ve dönemsel olarak izlenmesi gerekmektedir. Bazı örneklerde gözlenen bu elementlerdeki artışların bölgede gözlenen maden yatakları ile ilişkili olabileceği düşünülmüştür. Schoeller sınıflamasına göre ise suların 'çok iyi kaliteli sular' sınıfında yer aldığı belirlenmiştir.

\section{Teşekkür}

Bu çalışma, birinci yazarın Gümüşhane Üniversitesi, Fen Bilimleri Enstitüsü, Jeoloji Mühendisliği Anabilim Dalında yapmış olduğu yüksek lisans tez çalışmasından üretilmiştir. Ayrıca, Gümüşhane Üniversitesi Bilimsel Araştırma Projeleri (GÜBAP) Koordinatörlüğü'nce de desteklenmiştir. Proje No: 19.F5114.07.02. Saha çalışmalarındaki yardımlarından dolayı Nadire YAZICI, Yasin MERDAN ve Mustafa Gürbüz YAZICI'ya, su analizlerinin gerçekleşmesindeki katkılarından dolayı Ali GÜNDOĞDU ve Cemalettin BALTACI'ya ve çalışmanın her aşamasında desteklerini esirgemeyen Ferkan SIPAHI, Nafız MADEN ve Enver AKARYALI'ya teşekkür ederiz. Ayrıca, makalenin inceleme ve değerlendirme aşamasında yapmış oldukları katkılardan dolayı Baş Editör Prof. Dr. Halil AKINCI ve hakemlere şükranlarımızı sunarız.

\section{Kaynaklar}

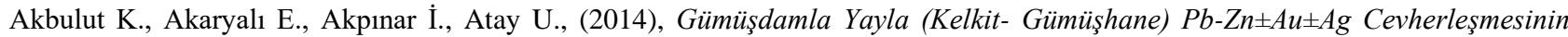
Petrografisi ve Cevher Mikroskobisi. 67. Türkiye Jeoloji Kurultayı, MTA, Ankara.

Akbulut K., Akaryalı E., Aydınçakır E., Akpınar, İ., (2015), Ünlüpınar Kelkit Gümüşhane Pb Zn Au Cevherleşmesinin Jeolojik Jeokimyasal ve Kökensel Olarak Incelenmesi, Gümüşhane Üniversitesi Fen Bilimleri Enstitüsü Dergisi, 5(1), 34-39.

Akın H., (1979), Geologie, Magmatismus und Lagerstättenbildung im ostpontischen Gebirge/Türkei aus der Sicht der Plattentektronik, Geologische Rundschau, 68, 253-283.

Akınc1 Ö.T., (1984), The Eastern Pontide Volcano-sedimentary Belt and Associated Massive Sulphide Deposits, in: Dixon, J.E., Robertson, A.H.F. (Eds), The Geological Evolution of the Eastern Mediterranean: Geological Society, London, Special Publications 17(1), 415-428.

APHA, AWWA, WEF, (2017), Standard Methods for the Examination of Water and Wastewater, 23rd Edition, Washington DC, USA.

Appelo C.A.J., Postma D., (2005), Geochemistry, Groundwater and Pollution (second edition), A.A. Balkema Publishers, Leiden, the Netherlands, 598ss.

Atabey E., (2005), Tıbbı Jeoloji, TMMO Jeoloji Mühendisleri Odası Yayınları, 124-134.

Balaram V., Vummiti D., Roy P., Taylor C., Kar P., Raju A.K., Abburi K., (2013), Determination of Precious Metals in Rocks and Ores by Microwave Plasma-Atomic Emission Spectrometry for Geochemical Prospecting Studies. Current Science, 104 (9), $1207-$ 1215.

Baysal A., (1999), Beslenme, Hatipoğlu Yayınevi, Ankara, ss. 131-147.

Bergougnan H., (1976), Structure de la Chaine Pontique dans le HautKelkit (nord-est de l'Anatolie), Bulletin de la Société Géologique de France, 18, 675-686.

Cederstorm D.J., (1946), Genesis of groundwater in the coastal plain of Virginia, Environmental Geology, 41, 218-245.

Çoğulu E., (1975), Gümüş̧ane ve Rize Granitik Plütonlarının Mukayeseli Petrolojik ve Jeokronometrik Etüdü, Doçentlik Tezi, İ̈ Maden Mühendisliği, İstanbul. 
Das B.K., Kaur P., (2001), Major ion chemistry of Renuka lake and weathering processes, Sirmaur district, Himachal Pradesh, India. Journal of Environmental Geology, 40, 908-917.

Dokuz A., (2011), A Salb Detachment and Delemanition Model for the Generation of Carboniferous High Potassium I-Type Magmatisim in the Easrtern Pontides: The Köse Composite Pluton, Gondwana Research, 19, 926-944.

Dündar Y., Aslan R., (2005), Yaşamı Kuşatan Ağır Metal Kurşunun Etkileri, Kocatepe Tıp Dergisi, 6, 1-5.

Freeze R.A., Cherry J.A., (1979), Groundwater. Prentice-Hall Inc., Englewood Cliffs, vol. 7632, 604, USA.

Gibbs R.J., (1970), Mechanism Controlling World Water Chemistry. Science 170 (3962), 1088-1090.

Göncüoğlu M.C., (2010), Türkiye Jeolojisine Giriş: Alpin ve Alpin Öncesi Tektonik Birliklerin Jeodinamik Evrimi. MTA Genel Müdürlüğü, Monografi Serisi No: 5. Ankara 69s.

Güler Ç., Çobanoğlu Z., (1994), Su Kirliliği. Çevre Sağlı̆̆ Temel Kaynak Dizisi. No: 12, Ankara. ISBN 975-7572-60-8.

Gültekin F., Dilek R., (2005), Gümüşhane Yöresi Mineralli Su Kaynaklarının İz Element ve Radyoaktivite İçerikleri. Jeoloji Mühendisliği Dergisi, 29, 36-43.

Gültekin F., (1998), Gümüşhane ve Bayburt Yöresi Mineralli Su Kaynaklarının Hidrokimyası ve İzotopik Özellikleri. Doktora Tezi, Karadeniz Teknik Üniversitesi, Fen Bilimleri Enstitüsü, Trabzon.

Güven İ.H., (1993), Doğu Karadeniz Bölgesi'nin 1/25.000 Ölçekli Jeolojisi ve Komplikasyonu. MTA, Ankara.

Jankowski K., Yao J., Kasiura K., Jackowska A., Sieradzka A., (2005), Multielement Determination of Heavy Metals in Water Samples by Continuous Powder Introduction Microwave-Induced Plasma Atomic Emission Spectrometry After Preconcentration on Activated Carbon. Spectrochimica Acta Part B: Atomic Spectroscopy, 60, 369-375.

Kandemir R., Y1lmaz C., (2009), Lithostratigraphy, Facies and Deposition Environment of the Lower Jurassic Ammonitico Rosso Type Sediments (ARTS) in the Gumushane Area, NE Turkey: Implications for the Opening of the Northern Branch of the Neo-Tethys Ocean, Journal of Asian Earth Sciences, 34, 586-598.

Karslı O., Dokuz A., Kandemir R., (2016), Subduction-related Late Carboniferous to Early Permian Magmatism in the Eastern Pontides, the Camlik and Casurluk Plutons: Insights from Geochemistry, Whole-rock Sr-Nd and In Situ Zircon Lu-Hf Isotopes, and $\mathrm{U}-\mathrm{Pb}$ Geochronology. Lithos, 266-267, 98-114.

Katz B.G., Coplen T.B., Bullen T.D., Davis J.H., (1998). Use of Chemical and Isotopic Tracers to Characterize the Interaction between Groundwater and SurfaceWater in Mantled Karst. Groundwater, 35, 1014-1028.

Kaygusuz A., Arslan M., Sipahi F., Temizel İ., (2016), U-Pb Zircon Chronology and Petrogenesis of Carboniferous Plutons in the Northern Part of the Eastern Pontides, NE Turkey: Constraints for Paleozoic Magmatism and Geodynamic Evolution. Gondwana Research, 39, 327-346.

Matthess G., (1982), The Properties of Groundwater. J.C. Haryey, John Wiley and Sons., Inc., Canada, 406ss.

Maya A.L., Loucks M.D., (1995), Solute and Isotopic Geochemistry and Groundwater Flow in the Central Wasatch Range, Utah, Journal of Hydrology, 172 (1-4), 31-59.

McNeely R.N., Neimanis V.P., Dwyer L., (1979), Water Quality Sourcebook-A Guide to Water Quality Parameters: Inland Waters Directorate, Water Quality Branch, Ottowa, Canada, 88ss.

Okay A.İ., Şahintürk Ö., (1997), Geology of the Eastern Pontides, in: Robinson, A.G. (Ed), Regional and Petroleum Geology of the Black Sea and Surrounding Region. AAPG Bulletin, 68, 291-311.

Okay A.İ., Tüysüz O., (1999), Tethyan Sutures of Northern Turkey. The Mediterranean Basin: Tertiary Extension within the Alpine Orogen, Geological Society London Special Publications, 156, 475-515.

Okay A.İ., (1989), Tectonic Units and Sutures in the Pontides, Northern Turkey, in: Sengör, A.M.C. (Ed), Tectonic Evolution of the Tethyan Region: NATO ASI Series C259, Kluwer, Dordrecht, 109-116.

Okay A.I.., (2008), Geology of Turkey: A Synopsis. Anschnitt, 21, 19-42.

Özbolat G., Tuli A., (2016), Ăğr Metal Toksisitesinin İnsan Să̆lı̆̆ına Etkileri. Arşiv Kaynak Tarama Dergisi, 25(4), $502-521$.

Pelin S., (1977), Alucra (Giresun) Güneydoğu Yöresinin Petrol Olanaklarl Bakımından Jeolojik İncelemesi, KTÜ Yayınları, 87, 103.

Piper A.M., (1944), A Graphic Procedure in the Geochemical Interpretation of Water Analyses. Transactions of the American Geophysical Union, 25, 914-923.

Sarin M.M., Krishnaswamy S., Dilli K., Somayajulu B.L.K., Moore W.S., (1989), Major ion chemistry of the Ganga-Brahmaputra river system: Weathering process and fluxes to the Bay of Bengal. Geochimica et Cosmochimica Acta, 53, 997-1009.

Schoeller H., (1955), Géochimie des eaux souterraines. Rev. Inst. Franç. Pétrole, Paris, 10. No. 3-4.

Schoeller H., (1965), Hydrodynamique Lans Lekarst (Ecoulemented Emmagusinement). Actes Colloques Doubronik, I, AIHS et UNESCO, ss. 3-20.

Schoeller H., (1977), Geochemistry of groundwater. In: Groundwater studies - An international guide for research and practice. UNESCO, Paris, Ch. 15, ss.1-18.

Sipahi F., (2005), Zigana Dağı (Torul-Gümüşhane) Volkanitlerindeki Hidrotermal Ayrışmaların Mineraloji ve Jeokimyası, Doktora Tezi, Karadeniz Teknik Üniversitesi Fen Bilimleri Enstitüsü. Trabzon.

Sipahi F., Sadıklar M.B., (2014), Geochemistry of Dacitic Volcanics in the Eastern Pontides (NE Turkey). Geochemistry International, 4, 329-349.

Sipahi F., Uslu S., (2016), Investigation of the Quality and Physical-Geochemical Characteristics of the Drinking Water in Gümüşhane (Turkey) City Central. Arabian Journal of Geosciences, 9, 600. doi: 10.1007/s12517-016-2620-6.

Sipahi F., Gücer M.A., Sadıklar M.B., (2019), Zigana Dağı (Gümüşhane, KD Türkiye) Dayklarının Jeokimyası ve Jeolojik Anlamı. Yerbilimleri, 40(3), 293-325.

Sipahi F., Gücer M.A., Sadıklar M.B., (2020), Nature of clays in Late Cretaceous dacitic rocks in the eastern Sakarya Zone (NE Turkey): A geochemical and isotopic approach. Turkish Journal of Earth Sciences, 29 (6), 831-852.

Soylak M., Doğan M., (2000), Su Kimyası. Erciyes Üniversitesi Yayınları Yayın No: 120, Kayseri, ss.79-83.

Stallard R.F., Edmond J.M., (1983), Geochemistry of the Amazon: 2. The Influence of Geology and Weathering Environment on the Dissolved Load. Journal of Geophysical Research: Oceans, 88 (C14), 9671-9688.

Stumm W., Morgan J.J., (1970), Aquatic Chemistry: An Introduction Emphasizing Chemical Equilibria in Natural Waters, New York: Wiley-Interscience, $583 \mathrm{ss}$ 
Subramani T., Rajmohan N., Elango L., (2010), Groundwater geochemistry and identification of hydrogeochemical processes in a hard rock region, Southern India. Environmental Monitoring and Assessment, 162, 123-137.

Şengör A.M.C., Yılmaz Y., (1981), Tethyan Evolution of Turkey: a Plate Tectonic Approach. Techtonophysics, 75, 181-241.

Tokel S., (1972), Stratigraphical and Volcanic History of the Gümüşhane Region (Ne Turkey). PhD Thesis, University Colloge, London.

Topuz G., Altherr R., (2004), Pervasive Rehydration of Granulites During Exhumation-an Example from the Pulur Complex, Eastern Pontides, Turkey. Mineralogy and Petrology, 81, 165-185.

Topuz G., Altherr R., Schwarz W.H., Dokuz A., Meyer H.P., (2007), Variscan Amphibolite-Facies Rocks from the Kurtoğlu Metamorphic Complex. Gümüşhane Area, Eastern Pontides, Turkey. International Journal of Earth Sciences, 96, 861-873.

Topuz G., Altherr R., Wolfgang S., Schwarz W.H., Zack T., Hasanözbek A., Mathias B., Satır M., Şen C., (2010), Carboniferous highPotassium I-Type Granitoid Magmatism in the Eastern Pontides: The Gümüshane Pluton (NE Turkey). Lithos, 116, 92-110.

TSE, (2005), TS 266, Türk İçme Suyu Standartları. Türk Standartları Enstitüsü, Ankara.

URL-1, (2011), Agilent 4100 Microwave Plasma Atomic Emission Spectrometer. Agilent Technologies, Inc., https://www.agilent.com/ en/products/mp-aes/mp-aes-systems/4100-mp-aes. [Erişim 08 Nisan 2019].

URL-2, (2012), Yerüstü Su Kalitesi Yönetimi Yönetmeliği, Resmi Gazete 28483 (Değişik: RG-10/8/2016-29797), Orman ve Su İşleri Bakanlığı, Ankara, https://www.resmigazete.gov.tr/eskiler/2016/08/20160810-9.htm. [Erişim 11 Mart 2019].

Uslu S., (2014), Gümüşhane Il Merkezi İ̧̧me Sularının Fiziksel ve Jeokimyasal Özelliklerinin İncelenmesi. Yüksek Lisans Tezi, Gümüşhane Üniversitesi, Fen Bilimleri Enstitüsü, Gümüşhane.

Vysetti B., Vummiti D., Roy P., Taylor C., Kamala C.T., Satyanarayanan M., Kar P., Subramanyam K.S.V., Raju A.K., Abburi K., (2014), Analysis of Geochemical Samples by Microwave Plasma-AES. Atomic Spectroscopy, 35 (2), 65-78.

WHO, (2014), Guidelines for Drinking-water Quality (Third Edition), Incorporating the First and Second Addenda, https://www.who.int/water_sanitation_health/dwq/gdwq0506.pdf. [Erişim 11 Mart 2019].

Yılmaz Y., (1972), Petrology and Structure of the Gümüşhane Granite and Surrounding Rock, NE Anatolia. PhD Thesis, University of London, UK.

Yılmaz Y., Tüysüz O., Yiğitbaş E., Genç Ş.C., Şengör A.M.C., (1997), Geology and Tectonics of the Pontides, in: Robinson, A.G. (Ed), Regional and Petroleum Geology of the Black Sea and Surrounding Region. AAPG Memoirs, 68, 183-226.

Yousef A.F., Saleem A.A., Baraka A.M., Aglan O.S.H., (2009), The Impact of Geological Setting on the Groundwater Occurrences in some Wadis in Shlatein-Abu Ramad Area, SE Desert, Egypt. European Water, 25(26), 53-68.

Zaloğlu N., (2001), Manganezin Biyolojik Sistemlerdeki Etkileri. Türk Biyokimya Dergisi, 26 (2), 61-69. 